\title{
1 FtsH Protease Inactivation Allows Accumulation of Aberrant Photosystem II in a
}

2 Chlamydomonas Rubredoxin Mutant

Robert H. Calderon ${ }^{1,2 *}$ Catherine de Vitry $^{3}$, Francis-André Wollman ${ }^{3}$ and Krishna K. Niyogi,4,5

${ }^{1}$ Department of Plant and Microbial Biology, University of California, Berkeley, CA 94720-

7 3102, USA

${ }^{2}$ Umeå Plant Science Centre, Department of Plant Physiology, Umeå University, 90187 Umeå, 10 Sweden

${ }^{3}$ Institut de Biologie Physico-Chimique, Unité Mixte de Recherche 7141, Centre National de la Recherche Scientifique and Sorbonne Université, Institut de Biologie Physico-Chimique, 75005

14 Paris, France

${ }^{4}$ Molecular Biophysics and Integrated Bioimaging Division, Lawrence Berkeley National

Laboratory, Berkeley, CA 94720, USA

${ }^{5}$ Howard Hughes Medical Institute, University of California, Berkeley, CA 94720 USA

*Corresponding author: Robert H. Calderon (robert.calderon@umu.se) 


\section{Abstract}

The assembly of photosystem II (PSII) requires the participation of assembly proteins that facilitate the step-wise association of its protein and pigment components into a functional complex capable of oxidizing water and reducing plastoquinone. We previously identified one such factor, the membrane-bound rubredoxin RBD1, but its precise role remains unknown in part due to the inability of the 2pac mutant strain of Chlamydomonas reinhardtii, which lacks RBD1, to accumulate PSII. Here, we show that decreased PSII accumulation in $2 p a c$ is due to increased proteolytic degradation. Inactivating the thylakoid membrane $\mathrm{FtsH}$ protease in the 2pac mutant background led to an increase in the abundance of PSII subunits and their integration into higher molecular weight complexes, including PSII dimers, capable of sustaining photoautotrophic growth. Dark- and low light-grown 2pac ftsh $1-1$ both accumulated a 23-kD fragment of the D1 protein, a marker typically associated with structural changes resulting from photodamage or photoinhibition. We introduced a HIS-tagged version of the PsbH protein into the 2pac ftshl-1 background to purify and examine PSII. We found no detectable changes with respect to cofactor composition relative to the wild-type, leading to us to propose a model in which RBD1 promotes the proper folding of D1, possibly via delivery or reduction of the non-heme iron during PSII assembly. Our results demonstrate that introduction of the ftsh 1-1 mutation into mutants defective in the biogenesis of thylakoid membrane complexes can allow for the accumulation and study of aberrant complexes that would otherwise be degraded due to their high protease sensitivity.

\section{Introduction}

Photosystem II (PSII) is a light-driven water:plastoquinone oxidoreductase essential for the growth of all oxygenic photoautotrophic organisms. In generating oxygen as a byproduct, it also enables the growth of most, if not all, aerobic organisms on the planet. The assembly of PSII occurs in a step-wise process that requires a variety of assembly factors, some of which are conserved from cyanobacteria to higher plants (de Vitry et al., 1989; Nixon et al., 2010; Komenda et al., 2012; Nickelsen and Rengstl, 2013; Spaniol et al., 2022). In a previous publication, we isolated and characterized cyanobacterial, algal and plant mutants lacking one such assembly factor, a highly conserved rubredoxin called RubA in cyanobacteria or RBD1 in photosynthetic eukaryotes (Calderon et al., 2013). Rubredoxins are small iron-containing proteins that function in electron transfer reactions. The RubA/RBD1 protein is associated with thylakoid membranes (Shen et al., 2002) and required for the assembly of PSII in Synechocystis sp. strain PCC 6803, Chlamydomonas reinhardtii, and Arabidopsis thaliana (Calderon et al., 2013), and it was later determined to be associated with intermediate complexes during PSII assembly rather than mature, fully assembled PSII (García-Cerdán et al., 2019; Kiss et al., 2019). In Chlamydomonas, RBD1 appears to have roles both in assembly of PSII intermediate complexes and in photoprotection during PSII assembly and repair (García-Cerdán et al., 2019). However, further elucidation of the specific role of RBD1 has been limited by our inability to isolate and study PSII that assembles in the absence of RBD1 because of the low accumulation of PSII subunits and complexes in rbdl mutants.

The FtsH protease complex is a membrane-localized ATP-dependent protease found in all oxygenic photoautotrophs (Lindahl et al., 1996). It has a well-characterized role in the degradation of damaged PSII subunits during photoinhibitory and oxidative stresses (Lindahl et al., 2000), and it has also been implicated in the degradation and remodeling of cytochrome $b_{6} f$ (cyt $b_{6} f$ ) complexes (Malnoë et al., 2014). In Chlamydomonas, the thylakoid membrane-anchored 
FtsH protease exists as a heterocomplex comprised of FtsH1 and FtsH2 isoforms (Malnoë et al., 2014). Strikingly, two Chlamydomonas $c c b$ mutants, which normally lack cyt $b_{6} f$ complexes due to mutations in cyt $b_{6} f$ assembly factors, were found to be able to accumulate aberrant forms of cyt $b_{6} f$ in a ftsh1-mutant background (Malnoë et al., 2011).

Here we have examined the role of the RBD1 protein in the assembly of PSII in Chlamydomonas by inactivating the FtsH protease in the 2pac mutant, which lacks RBD1. We show that combining the ftsh 1-1 and 2pac mutations permits the accumulation of a misassembled variant of PSII. We find that accumulation of this variant PSII is sufficient to allow photoautotrophic growth in the absence of RBD1, and thus we show that inactivation of FtsH can be a powerful tool for studying the role of PSII assembly factors.

\section{Results}

\section{The lack of PSII in 2pac is due to instability of PSII subunits rather than a defect in translation}

Given that the assembly of PSII monomers occurs to a much lower extent in the 2pac mutant than in the wild type (García-Cerdán et al., 2019), we sought to investigate whether the decrease in PSII accumulation might be caused by a defect in translation of chloroplast-encoded PSII subunits. We therefore pulse-labeled Chlamydomonas cells for several minutes in order to detect rates of protein translation rather than rates of degradation. Wild-type (4A+ or T222), $2 p a c$, and the $\triangle p s b A$ strain Fud7 (Bennoun et al., 1986) cells were grown on acetate as a carbon source and allowed to reach logarithmic growth phase before being pulse-labeled with $\left[{ }^{14} \mathrm{C}\right]-$ acetate for $7 \mathrm{~min}$ in the presence of cycloheximide (to inhibit cytosolic translation). As shown in Fig. 1A, there were no major differences in the incorporation of the radioactive signal into newly synthesized proteins between 4A+, T222, 2pac, and Fud7 (with the exception of D1 for Fud7). The assignment of the PSII proteins D1 (PsbA), D2 (PsbD), CP43 (PsbC) and CP47 (PsbB) is based on mutant analysis (de Vitry et al., 1989). Levels of radiolabeled CP47, CP43 and cytochrome $f$ are slightly lower in 2pac relative to both WT strains and Fud7, but these proteins are clearly being actively translated.

Because subunits of PSII are being translated in 2pac, we hypothesized that the lack of accumulation of PSII complexes might be due to instability of PSII subunits. To test this, wild-

101

102

103

104

105

106

107

108 type, Fud7, and 2pac cells were allowed to reach logarithmic growth phase before adding chloroplast translation inhibitors (lincomycin and chloramphenicol). Samples were collected at three time points $(0,1$, and $4 \mathrm{~h}$ after incubation) for immunoblot analysis. These immunochase data showed that, over the time course, the PSII subunits D1, D2, and CP43 all rapidly disappeared in 2pac, whereas they remained stable in wild-type cells (Fig. 1B). In the Fud7 strain, D1 was absent, and D2 and CP43 were unstable, as expected (de Vitry et al., 1989). In contrast to PSII proteins, the $\alpha$ and $\beta$ subunits of the chloroplast ATP synthase were stable in all three strains (Fig. 1B). The data therefore suggest that genes encoding thylakoid membrane proteins are all transcribed and translated in 2pac, and the lack of PSII is due to the specific degradation or instability of PSII subunits relative to subunits of other photosynthetic complexes.

\section{2pac ftsh1-1 accumulates higher levels of PSII subunits and complexes than 2pac}

Given the well-established role of FtsH in the degradation of damaged PSII, we hypothesized that the introduction of the ftsh $1-1$ mutation into the $2 p a c$ strain could result in a decrease in the degradation of PSII subunits and thus an increase in steady-state levels of these

116 proteins. To test this, we first crossed the 2 pac and ftsh $1-1$ strains and isolated 2 pac ftsh $1-1$ 
double mutants (Supplemental Fig. 1). We then measured the accumulation of PSII subunits in these strains by immunoblot analysis after growth in low light. As shown in Fig. 2, there was a marked increase in the amounts of D1, D2, CP43, and CP47 in the 2pac ftsh1-1 strain relative to both the parental 2pac strain and the 2pac progeny isolated from the same tetrad, although the levels of these PSII subunits were not as high as in the wild-type or ftsh $1-1$ strains. This pattern was observed in all tested 2pac ftsh 1-1 progeny (Supplemental Fig 2). In addition, immunodetection with an antibody raised against the loop connecting helices D and E of the D1 protein ( $\alpha$-DE loop) revealed a band at $23 \mathrm{kD}$ in 2pac ftsh 1-1 and ftsh1-1 (Fig. 2). This fragment has been detected in the single ftsh 1-1 mutant only in the light and under various stress conditions (Malnoë et al., 2014). It has been attributed previously to a photodamage-induced cleavage product of the full-length D1 protein (De Las Rivas et al., 1992) as well as a translational pause intermediate of D1 (Mullet et al., 1990). In contrast, the wild-type strains did not accumulate any of the $23-\mathrm{kD}$ fragment under the tested conditions. The intensity of the 23$\mathrm{kD}$ fragment band (relative to full-length D1) was much higher in 2pac ftsh 1-1 than in ftshl-1, suggesting an increased PSII light sensitivity of 2pac ftshl-1 compared to ftshl-1.

To determine the assembly status of the PSII subunits in the 2pac ftsh $1-1$ mutant, we isolated thylakoid membranes from cells grown photoheterotrophically at $6 \mu$ mol photons $\mathrm{m}^{-2} \mathrm{~s}^{-1}$ and examined whether or not PSII subunits were being incorporated into complexes by 2DPAGE analysis. In previous work with the 2 pac mutant, PSII subunits were found to assemble into PSII monomers but not dimers or supercomplexes (García-Cerdán et al., 2019). However, in the 2pac ftsh1-1 mutant, we detected these subunits in both PSII monomers and dimers (Fig. 3), indicating that these subunits were not only accumulating to greater levels (Fig. 2) but also being incorporated into higher molecular weight complexes. Additionally, in the 2pac ftsh 1-1 mutant, some of the D2 subunit appeared to accumulate into a subcomplex of smaller molecular weight than the CP43-less PSII assembly intermediate RC47 complex (indicated by an arrow in Fig. 3). These smaller subcomplexes were not detected in the ftsh 1-1 mutant.

\section{2pac ftsh1-1 grows photoautotrophically in low light and exhibits variable fluorescence}

We next examined whether the PSII complexes that accumulate in $2 \mathrm{pac} f \mathrm{fsh} 1-1 \mathrm{can}$ sustain photoautotrophic growth. As shown in Fig. 4A, the 2pac ftshl-1 mutant was able to grow slowly under low light conditions on minimal medium, indicating that the PSII in this strain is at least partially functional. To test the activity of PSII under the same light conditions, we measured variable chlorophyll fluorescence to calculate the maximum efficiency of PSII ( $\left.\mathrm{F}_{\mathrm{v}} / \mathrm{F}_{\mathrm{m}}\right)$ and found that 2pac ftshl-1 exhibited low levels of variable fluorescence (Fig. 4B). The 2pac ftsh 1-1 mutants displayed more variable fluorescence when grown at very low light on solid medium (Fig. 4B and Supplemental Fig. 3) than when grown at low light in strongly aerated liquid cultures (Fig. 4C and Supplemental Fig. 4), suggesting oxygen- and/or light-dependent loss of PSII activity.

\section{Dark-grown 2pac ftsh 1-1 displays variable fluorescence and accumulates a distinctive fragment of the $D 1$ protein}

We took advantage of the ability of Chlamydomonas to synthesize chlorophyll in the dark as well as in the light (Beale, 2009) to determine whether the PSII in 2pac ftsh1-1 might be light sensitive. To address this possibility, we grew the 2pac ftsh $1-1$ mutant in darkness and again assayed $F_{v} / F_{m}$ (Fig. 5A). The dark-grown mutant cells displayed an appreciable increase in

$162 \quad \mathrm{~F}_{\mathrm{v}} / \mathrm{F}_{\mathrm{m}}$, consistent with higher levels of functional PSII. 
We hypothesized that the low-light inactivation of PSII in 2pac ftsh $1-1$ might be due to either decreased abundance of PSII in the light or to a structural or conformational difference between these reaction centers and those from the wild-type. To test this, we first compared the accumulation of PSII subunits in dark-grown wild-type, 2pac, and 2pac ftsh $1-1$ cells. As shown in Fig. 5B, the accumulation of PSII subunits is comparable between dark-grown wild-type and $2 p a c$ ftsh $1-1$ cells. While overall accumulation of mature proteins was comparable, we noted that immunodetection with the $\alpha$-DE loop antibody revealed a band at $23 \mathrm{kD}$ in dark-grown $2 p a c$ ftsh $1-1$ and not in the wild type (Fig. 5B), as was also the case in light-grown 2pac ftshl-1 (Fig. 2). Because this D1 fragment is absent in the dark-grown single ftshl-1 mutant (Malnoë et al., 2014) and dark-grown 2pac (Fig. 5B) but present in the dark-grown double 2pac ftsh1-1 mutant (Fig. 5B), it arises as a consequence of combining the $2 \mathrm{pac}$ mutation with inactivation of the thylakoid protease FtsH.

\section{Purification and characterization of PSII from dark-grown 2pac ftsh1-1 cells}

We hypothesized that the presence of the $23-\mathrm{kD}$ fragment of the $\mathrm{D} 1$ protein in darkgrown 2pac ftsh $1-1$ cells might be due to a structural difference between PSII reaction centers from this strain, relative to the wild type. Therefore, we purified PSII from both the 2 pac ftsh $1-1$ strain and the wild type so they could be compared. To enable purification of PSII from $2 p a c$ ftsh 1-1, we introduced a genetically encoded HIS-tag on the lumenal side of the PsbH subunit of PSII by crossing the 2pac ftsh1-1 mutant to the H-HIS strain (Cullen et al., 2007). Seven full tetrads were obtained. Progeny were genotyped by PCR to determine FTSH1 and RBD1 alleles, and one progeny (T7A) which contained the 2pac and ftshl-1 mutant alleles was selected for further analysis (Supplemental Fig. 5A). Because $p s b H$ is a chloroplast-encoded gene and chloroplast inheritance is uniparental from the mating type + parent, all progeny were expected to express the HIS-tagged PsbH protein. Both the presence of PsbH-HIS and the absence of RBD1 were confirmed via immunoblot (Supplemental Fig. 5B).

T7A and H-HIS were grown on acetate in darkness, and the HIS-tagged PSII complex was purified by Ni-affinity chromatography. After isolation, the PSII samples were examined via BN-PAGE, and PSII monomers, dimers, and supercomplexes were observed in both H-HIS and T7A. (Fig. 6A). As shown in Fig. 6B, the PSII monomer from both H-HIS and T7A contained D1, D2, CP47, CP43, and HIS-tagged PsbH. To determine whether additional subunits might be lacking from the T7A dimer (or if assembly factors absent in H-HIS remained bound in T7A), the gel slices corresponding to the monomer were analyzed via LC-MS/MS (Table 1). The presence of D1, D2, CP47, CP43 and PsbH was confirmed as well as the additional presence of PsbO, PsbE, and PsbF in both H-HIS and T7A.

Given a previously hypothesized role for RBD1 in facilitating the photoprotection of nascent PSII complexes via an interaction with cytochrome $b_{559}$ (García-Cerdán et al., 2019), we sought to examine whether the properties of cytochrome $b_{559}$ were altered in the absence of RBD1. Both subunits of cytochrome $b_{559}$ (PsbE and PsbF) were detected in PSII from T7A via mass spectrometry (Table 1), so we also tested for the presence of the heme coordinated by these proteins by recording reduced minus oxidized UV-vis absorption spectra of isolated PSII from H-HIS and T7A. As shown in Fig. 6C, both samples exhibited a strong peak centered at $559 \mathrm{~nm}$, indicating that the PsbE and PsbF subunits detected by mass spectrometry do indeed coordinate the heme cofactor of cytochrome $b_{559}$. 


\section{Discussion}

We have previously shown that the Chlamydomonas 2pac mutant lacking the RBDl gene is specifically deficient in PSII accumulation (Calderon et al., 2013). Our detection of wild-type levels of D1 and D2 protein synthesis in 2pac rules out a role for RBD1 in enabling the translation of these PSII subunits. We did observe a modest reduction in CP47, CP43 and cytochrome $f$ protein synthesis in $2 p a c$ relative to WT, indicating that RBD1 may play a direct or indirect role in promoting their translation. However, the results from the immunochase experiment and the increased accumulation of PSII in the 2pac ftsh $1-1$ double mutant show that the low levels of PSII in 2pac are due in major part to a post-translational instability of PSII subunits that can be partly alleviated by specific inactivation of the thylakoid-localized FtsH protease (Fig. 1 and Fig. 2). These data are consistent with the results obtained on the cyanobacterial mutant lacking the RBD1 ortholog RubA (Kiss et al., 2019), in which the $\triangle r u b A$ mutant was found to synthesize PSII subunits.

\section{PSII that accumulates in 2pac ftsh 1-1 is highly sensitive to light and possibly structurally distinct from wild-type PSII}

We found that 2pac ftsh 1-1 strain was able to grow photoautotrophically (Fig. 4A) indicating that at least some amount of functional PSII was present since it was able to sustain growth. These results are consistent with the observation that the cyanobacterial $\triangle r u b A$ mutant is able to grow photoautotrophically in the absence of RubA (Calderon et al., 2013; Kiss et al., 2019). We detected more PSII activity in 2pac ftsh $1-1$ when grown under low light on plates (Fig. 4B) than in strongly aerated cultures (Fig. 4C), suggesting oxygen- and/or light-dependent loss of PSII activity. The activity of PSII from 2 pac ftsh $1-1$ was the highest in dark-grown cells, as evidenced by the partial recovery of variable fluorescence (Fig. 5A).

The D1 protein of PSII is the main target of photodamage (Ohad et al., 1984). The accumulation of D1 fragments in the single $f t s h 1-1$ is consistent with proposed models for plant (Kato et al., 2012; Kato and Sakamoto, 2018) and algal chloroplasts (Malnoë et al., 2014) in which there is a joint action between Deg proteases (endoproteolytic cuts) and FtsH proteases (processive degradation) during the repair of photodamaged PSII. Our detection of the 23-kD fragment of D1 in dark-grown 2pac ftshl-1 cells (Fig. 5B) is highly unusual and suggests that the conformation of PSII in the mutant is altered. This fragment has been hypothesized to be either a degradation intermediate (De Las Rivas et al., 1992) or a product of translational pausing (Mullet et al., 1990). Reports presenting evidence that the fragment is due to degradation have hypothesized that it results from proteolysis (De Las Rivas et al., 1993; Keren et al., 1997; Spetea et al., 1999) or direct damage by reactive oxygen species (Miyao et al., 1995). In both cases, the trigger for degradation is thought to be photoinhibition, which would not occur in complete darkness. Indeed, the 23-kD fragment is not detected in dark-grown ftsh1-1 (Malnoë et al., 2014). However, if the trigger were instead a conformational change occurring as a result of photodamage or misfolding (as might be the case in the absence of RBD1), the observed data would support a model in which RBD1 is required for the proper folding of D1 during PSII assembly (Fig. 7). A conformational change has indeed been previously suggested to act as a signal recognized by proteases that catalyze cleavage (De Las Rivas et al., 1993; Nakajima et al., 1996; Spetea et al., 1999). Specifically, occupation of the $\mathrm{Q}_{\text {в }}$ site by the PSII inhibitor PNO8 ( $N$ octyl-3-nitro-2,4,6-trihydroxybenzamide) triggers the production of the 23-kD fragment in darkness, a process hypothesized to be due to PNO8-induced conformational changes at the DE 
shown to generate a 23-kDa and about 20-kDa fragment of D1, respectively, in vitro (Haussühl et al., 2001). Deg2 does not appear to have a role in D1 turnover after photoinhibition (Huesgen et al., 2006), but Deg7 participates in PSII repair in Arabidopsis in vivo (Sun et al., 2010). The Chlamydomonas genome encodes fourteen predicted Deg proteins (Schroda and de Vitry, 2022), 3 of which appear to be localized to the stroma. Based on sequence homology to two stromalocalized Arabidopsis proteins, Deg2 and Deg7 are likely found in the stroma (Schroda and Vallon, 2009; Schuhmann et al., 2012) while Deg1C, an ortholog of lumen-localized Arabidopsis Deg1, was experimentally identified in the stroma (Theis et al., 2019). Additionally, large-scale proteomic studies utilizing mass spectrometry have detected both Deg7 (Hemme et al., 2014) and Deg1C (Ramundo et al., 2014) . The sole study dedicated to a Chlamydomonas Deg mutant is the characterization of the deglC mutant which accumulates proteins involved in high light acclimation when grown at low light intensities (Theis et al., 2019). It is possible that Deg2, Deg7 and/or Deg1C function in PSII assembly quality control when RBD1 is absent, leading to production of the $23-\mathrm{kDa}$ fragment in darkness and its accumulation in the 2 pac ftsh $1-1$ strain but not in ftshl-1.

Alternatively, if the observed $23-\mathrm{kD}$ fragment is a translational pause product (Mullet et al., 1990), then RBD1 might be required to facilitate the full translation of D1. This model, however, is not supported by the results of our pulse-labeling experiments in which we observed no differences in the rate of translation of full-length D1 in the 2pac mutant (Fig. 1A), given our 7-minute pulse-labeling time which favors the detection of the rate of translation rather than the rate of degradation. However, the experiment requires a pulse under light since the incorporation of acetate is light-dependent, so it is still possible that pausing occurs in the dark.

The presence of aberrant PSII complexes in dark-grown 2pac ftsh 1 - 1 would be consistent with the proposed role of RBD1 and its cyanobacterial ortholog RubA in PSII assembly (GarcíaCerdán et al., 2019; Kiss et al., 2019), but not with its separate proposed function in protecting assembly intermediates from photooxidative damage (García-Cerdán et al., 2019). The role in PSII assembly is further supported by the accumulation of RC47 and a smaller PSII assembly subcomplex detected via 2D-PAGE of 2pac ftshl-1 thylakoids (Fig. 3) and in the observed interaction of RubA with two such PSII assembly subcomplexes during PSII assembly in cyanobacteria (Kiss et al., 2019).

\section{There are no detectable differences in protein composition of PSII from 2pac ftsh1-1 relative to the wild-type}

The extreme light-sensitivity of PSII from 2pac ftsh $1-1$ compared to the wild-type led us to hypothesize that there might be a difference in protein and/or cofactor composition between the mutant and wild-type reaction centers. Mass spectrometry analysis of purified PSII complexes was unable to resolve any differences in the presence or absence of subunits (Table 1). This technique, however, suffers from the limitation that the detection of small hydrophobic proteins, of which there are many in PSII, is difficult. Consequently, we were unable to detect many of the small subunits of PSII, two of which (PsbJ and PsbL) are encoded by genes that lie directly downstream of rubA in the genomes of nearly all cyanobacteria (Calderon et al, 2013). It is therefore possible that one or more of these subunits is absent in the reaction centers purified from 2pac ftshl-1.

Our detection of cytochrome $b_{559}$ in isolated PSII complexes indicates that the $b$-heme coordinated by PsbE and PsbF (cytochrome $b_{559}$ ) is unaltered in the 2 pac ftsh $1-1$ mutant and that $\mathrm{RBD} 1$ is unlikely to play a role in the maturation of cytochrome $b_{559}$. While rubredoxins have 
generally been described as redox-active electron transport proteins (Lovenberg and Sobel, 1965), a recent report demonstrated that the rubredoxin fold of the enzyme 3hydroxyanthranilate 3,4-dioxygenase (HAO) acts an iron reservoir (Liu et al., 2015). When iron is lost from the catalytic site of HAO, it is replenished by delivery of the so-called "spare tire" iron of the rubredoxin. RBD1 could conceivably serve a similar role for PSII, which binds a nonheme iron (Fig. 7). This non-heme iron is located at the electron acceptor side of PSII between the two quinones, $\mathrm{Q}_{\mathrm{A}}$ and $\mathrm{Q}_{\mathrm{B}}$. It is coordinated by four histidine residues, two from $\mathrm{D} 1$ and two from D2, and by a bicarbonate ion that provides a bidentate ligand (Umena et al., 2011; Kato et al., 2021). Many amino acid residues in the DE loop of the D1 protein, which are also in the vicinity of the non-heme iron (F239, Q241, E242, Y246), have been previously reported to undergo oxidation (Kumar et al., 2021), and the amino acids between 238 and 248 have been proposed to be the region where cleavage of the DE loop occurs in vivo (Greenberg et al., 1987). A model in which RBD1 functions in iron delivery is consistent with the observation that the cyanobacterial RubA interacts with D1 during the formation of the D1-D2 heterodimeric complex RCII (Kiss et al., 2019) but is not present in either of the direct precursors of RCII, the so-called D $1_{\text {mod }}$ and D2 $2_{\text {mod }}$ subcomplexes (Knoppová et al., 2022). The formation of the RCII complex is presumably accompanied by the insertion of the non-heme iron, given that both D1 and D2 provide the ligands for coordinating this metal (Fig. 7). Alternatively, RBD1/RubA could be involved in reduction of the non-heme iron (Calderon et al., 2013) during its ligation to the D1-D2 heterodimer. Both the non-heme iron of PSII and the iron-binding domain of RBD1/RubA are on the stromal side of the thylakoid membrane (Wastl et al., 2000; Umena et al., 2011; García-Cerdán et al., 2019; Kiss et al., 2019). Unfortunately, our attempts to detect the presence or absence of the non-heme iron of PSII via EPR and inductively coupled plasma-MS (ICP-MS) on isolated PSII from 2pac ftshl-1 were unsuccessful. Nonetheless, the possibility that RBD1 delivers or reduces the non-heme iron during PSII assembly is compatible with all currently available data.

\section{The ftsh1-1 mutant is a promising tool for studying mutations affecting thylakoid membrane complexes}

Our work and a similar study that used the ftsh $1-1$ mutation to accumulate and probe the function of a misassembled cytochrome $b_{6} f$ (Malnoë et al., 2011) have demonstrated the utility of this mutant in helping to understand PSII and cytochrome $b_{6} f$ biogenesis. Given the large number of FtsH-degradation targets in the plastid, future studies using the ftsh $1-1$ mutant should provide insights into the biogenesis and function of a variety of other thylakoid membrane proteins.

\section{Materials and Methods}

\section{Chlamydomonas strains, mutant generation, and growth conditions}

Wild-type (4A+) and mutant strains 2pac (Calderon et al., 2013), Fud7 (Bennoun et al., 1986), ftsh1-1 (Malnoë et al., 2014), H-HIS (Cullen et al., 2007), and 2pac ftsh1-1 were grown at $25^{\circ} \mathrm{C}$ on Tris acetate-phosphate (TAP) medium (Gorman and Levine, 1965) or high salt (HS) minimal medium (Sueoka, 1960) as indicated. Strains were grown at various light intensities from dark to $30 \mu \mathrm{mol}$ photons $\mathrm{m}^{-2} \mathrm{~s}^{-1}$, as indicated in the figure legends. Mutants were genotyped based on resistance to paromomycin (for 2pac) or by PCR (for 2pac or ftsh 1-1) as described (Calderon et al., 2013; Malnoë et al., 2014) or via immunodetection with an anti-His antibody (H-HIS). 
The 2pac (mating type +) and ftsh1-1 (mating type -) mutants were crossed. Four full tetrads, nine triads, and one dyad of the resulting progeny were assayed for the presence/absence of the ftsh 1-1 mutation by PCR (Supplemental Fig. 1A). To ensure the progeny were derived from successful mating, progeny were genotyped at the mating-type locus via PCR. All progeny groups showed a mixture of + and - mating types, indicating that they were derived from the cross (Supplemental Fig. 1B). Progeny were grown on TAP plates containing paromomycin to select for strains bearing the 2pac mutation (Supplemental Fig 1C). One particular strain, T3.4, that contained both mutations was selected for further characterization and is the strain identified as 2 pac ftshl-1 when only one strain is shown and not specified.

\section{$\left[{ }^{14} \mathrm{C}\right]$-acetate pulse-labeling}

Exponentially growing cells at $2 \times 10^{6}$ cells $\mathrm{mL}^{-1}$ from a $200 \mathrm{~mL}$ culture grown in TAP

\section{Immunochase}

Inhibitors of chloroplast gene translation (chloramphenicol, $100 \mu \mathrm{g} \mathrm{mL}^{-1}$ and lincomycin, $500 \mu \mathrm{g} \mathrm{mL}^{-1}$ ) were added to $400 \mathrm{~mL}$ of exponentially growing cells in low light and TAP. Cells were incubated, with shaking, at $6 \mu \mathrm{mol}$ photons $\mathrm{m}^{-2} \mathrm{~s}^{-1}$ over the course of $4 \mathrm{~h}$, and $50 \mathrm{~mL}$ of cells were harvested at 0,1 , and $4 \mathrm{~h}$ post-addition of inhibitors before extraction of proteins, as described (Calderon et al., 2013). Protein samples were separated by SDS-PAGE on 12-18\% polyacrylamide gels containing $8 \mathrm{M}$ urea before transfer via semi-dry transfer system and subsequent blotting with specific polyclonal antibodies against ATP synthase $\left(\mathrm{CF}_{1} \alpha\right.$ and $\beta$ subunits, PSII reaction center subunits D1-DE loop (Agrisera AS10704) and D2 (Agrisera AS06146), PSII core antennae CP43 and PSII extrinsic subunit OEE3.

\section{Chlorophyll fluorescence measurements}

Chlorophyll fluorescence kinetics were measured at room temperature on dark-adapted cells. A home-built fluorimeter with a green detecting light was used for measurements on 1-mL aliquots of liquid cultures (Rappaport et al., 2007) before and after the addition of PSII-specific inhibitor 3-(3,4-dichlorophenyl)-1,1-dimethylurea (DCMU; $10 \mu \mathrm{M})$. A fluorescence imaging system (BeamBio, SpeedZen camera) with a blue detecting light was used for measurements of plates as described (Johnson et al., 2009). The maximum quantum yield of PSII photochemistry 
$\left(\mathrm{F}_{\mathrm{v}} / \mathrm{F}_{\mathrm{m}}\right)$ was calculated as $\left(\mathrm{F}_{\mathrm{m}}-\mathrm{F}_{0}\right) / \mathrm{F}_{\mathrm{m}}$ where $\mathrm{F}_{0}$ is the fluorescence level of dark-adapted cells in the absence of DCMU $F_{m}$ is the maximum level of fluorescence in the presence of DCMU or after a saturating light pulse.

\title{
Analysis of thylakoid membrane proteins and complexes
}

SDS-PAGE and immunoblot analysis of proteins were performed as previously described (Calderon et al., 2013). Thylakoid membranes were isolated as described (Schottkowski et al., 2012). Briefly, cells were harvested at logarithmic growth phase $\left(2 \times 10^{6}\right.$ cells $\left.\mathrm{mL}^{-1}\right)$ and washed in MKT buffer (10 mM Tricine-KOH, pH 7.5, $20 \mathrm{mM} \mathrm{KCl,} 25 \mathrm{mM} \mathrm{MgCl}$, $5 \mathrm{mM}$ aminocaproic acid, $1 \mathrm{mM}$ benzamidine and $0.2 \mathrm{mM}$ PMSF) once before breaking by passage through a French pressure cell. Membranes were collected by centrifugation at 31,000 $\mathrm{g}$ for 30 minutes, then resuspended in ACA 750 (750 mM aminocaproic acid, $50 \mathrm{mM}$ Bis-Tris, $\mathrm{pH}$ 7.0, $0.5 \mathrm{mM}$ EDTA) to a concentration of $1 \mathrm{mg} \mathrm{mL}^{-1}$ chlorophyll. Membranes were solubilized by addition of an equal volume of ACA 750 containing $2 \%$ n-dodecyl $\beta$-D-maltoside ( $\beta$-DM, Anatrace) for a final concentration of $0.5 \mathrm{mg} \mathrm{mL}^{-1}$ chlorophyll and $1 \% \beta$-DM. Membranes were solubilized for 10 min on ice in the dark before centrifugation to pellet unsolubilized material. Solubilized membranes were then mixed 60:1 with loading buffer (100 mM BisTris-HCl, pH 7.0, 5\% Coomassie G-250, $0.5 \mathrm{mM}$ aminocaproic acid and 30\% sucrose) and loaded onto a 4-16\% precast BN-PAGE gel (Life Technologies). Second dimension analysis was performed by solubilizing BN-PAGE gel slices in 2x Laemmli buffer (Laemmli, 1970) and loading into precast 2D gels (Life Technologies).

Mass spectrometry experiments were performed at the Vincent J. Coates Protein Mass Spectrometry Facility. Bands were excised from BN-PAGE gels and subjected to analysis by reverse phase LC-MS/MS.

\section{Purification of HIS-tagged PSII}

PSII purification was performed as described (Cullen et al., 2007), with the following minor modifications. Cultures were grown in $10 \mathrm{~L}$ bottles with vigorous stirring and bubbled with filtered air. All purification steps were performed in the dark, and all buffers were supplemented with betaine to a final concentration of $1 \mathrm{M}$. To account for differences in protein/chlorophyll content in the 2pac ftsh 1-1 mutant, membranes from 2pac ftsh1-1 (T7A) were solubilized at final concentration of $0.6 \mathrm{mg} \mathrm{mL}^{-1}$ chlorophyll and $25 \mathrm{mM} \beta$-DM. Samples were further purified before analysis by MS by loading directly onto a precast 4-16\% BN-PAGE gel (Life Technologies).

\section{Supplemental data}

Supplemental Figure 1: Genotyping of progeny from cross of 2pac (mating type + ) and ftsh 1-1 (mating type -) and isolation of double mutant 2pac ftsh1-1.

\author{
Supplemental Figure 2: Immunoblot analysis of progeny from $2 p a c$ ftsh 1-1 cross showing \\ steady-state levels of PSII subunits.
}

\section{Supplemental Figure 3: 2pac ftsh1-1 strains display some variable fluorescence.}

Supplemental Figure 4: Light-grown 2pac ftsh 1-1 in liquid culture displays a very low PSII activity. 
Supplemental Figure 5: Isolation of 2pac ftsh1-1 double mutants in the H-HIS background.

\section{Funding}

This work was supported by the Centre national de la Recherche Scientifique and Sorbonne Université (basic support to Unité Mixte de Recherche 7141), by the Agence Nationale de la Recherche (projects ANR-07-BLAN-0114 and ANR-12-BSV8-0011) and by the 'Initiative d'Excellence' program from the French State (Grant 'DYNAMO', ANR-11-LABX-0011-01).

\section{Acknowledgements}

We thank Alizée Malnoë and Masakazu Iwai for extensive discussions, critical feedback, and experimental assistance. We thank Fabrice Rappaport, Alain Boussac, R. David Britt, Paul Oyala, David Marchiori, and Ruchira Chatterjee for technical assistance and helpful discussions. We also thank the 2pac and ftshl-1 strains for inspiring two of their human caretakers to make a human genetic cross ten years after the creation of the algal genetic cross. This work used the S10 Instrumentation Grant S10RR025622. K.K.N. is an investigator of the Howard Hughes Medical Institute. This article is subject to HHMI's Open Access to Publications policy. HHMI lab heads have previously granted a nonexclusive CC BY 4.0 license to the public and a sublicensable license to HHMI in their research articles. Pursuant to those licenses, the authoraccepted manuscript of this article can be made freely available under a CC BY 4.0 license

\section{Author Contributions}

RHC, CdV, F-AW and KKN designed the research, analyzed the data and wrote the paper. RHC and $\mathrm{CdV}$ performed the experiments.

\section{Figure 1: PSII subunits are translated, but unstable in the absence of RBD1. A) Plastid-} encoded proteins from $\left[{ }^{14} \mathrm{C}\right]$-acetate-radiolabeled wild-type $(4 \mathrm{~A}+$ and $\mathrm{T} 222)$, Fud7 $(\Delta p s b A)$, and $2 p a c$ whole-cell extracts separated by SDS-PAGE on a $12-18 \%$ polyacrylamide gel in the presence of $8 \mathrm{M}$ urea and visualized by autoradiography. PSII subunits are in black and indicated by arrows. Other photosynthetic proteins are labeled in gray. B) Immunoblot analysis of steadystate levels of $\alpha$ and $\beta$ subunits of plastid ATP synthase ( $\alpha, \beta$ CF1), D1, D2, and CP43 after 0,1 , or 4 hours of incubation with chloroplast translation inhibitors. All loaded samples contained 20 $\mu \mathrm{g}$ chlorophyll, with the exception of the "WT $10 \%$ ", which contained $2 \mu \mathrm{g}$ chlorophyll.

Figure 2: Inactivation of FtsH increases accumulation of PSII subunits in 2pac. Immunoblot analysis of PSII subunit levels from a representative tetrad (tetratype tetrad 1, right side) obtained by crossing 2pac and ftshl-1, with parental strains and wild-type as controls (left side). Whole-cell protein extracts from the strains grown in acetate-containing TAP medium at $6 \mu$ mol photons $\mathrm{m}^{-2} \mathrm{~s}^{-1}$ were separated by SDS-PAGE on a 12-18\% polyacrylamide gel in the presence of $8 \mathrm{M}$ urea and immunodetected with antibodies against PSII subunits (CP47, CP43 and D2) and a peptide of the loop between the transmembrane helices D and E of D1 (D1-DE loop). Coomassie protein staining is provided as loading control. 
Figure 3: Two-dimensional blue native (BN)/SDS-PAGE analysis of PSII in 2pac ftsh1-1 relative to parental strains. Thylakoid membrane complexes from WT (4A+), ftsh1-1, 2pac and 2pac ftsh $1-1$ were solubilized with $1 \% \beta$-DM and separated by BN-PAGE (top panels), followed by SDS-PAGE in the second dimension and immunoblot analysis to detect D2 and CP43 (lower panels). SC, PSII super complex; D, PSII dimer; M, PSII monomer; RC47, CP43less PSII assembly intermediate (Komenda et al., 2004). Smaller complexes specifically detected in 2pac ftsh1-1 with antibodies against D2 are indicated by an arrow.

Figure 4: 2pac ftsh1-1 grows photoautotrophically and displays low variable fluorescence. A) Growth on plates without (HS, left panel) and with (TAP, right panel) acetate at $30 \mu \mathrm{mol}$ photons $\mathrm{m}^{-2} \mathrm{~s}^{-1}$ of wild-type $(4 \mathrm{~A}+), 2 p a c, f t s h 1-1,2 p a c f t s h 1-1$, a strain lacking the psbA gene encoding the D1 protein (Fud7), and two complemented lines (gRBD1-1 and gRBD1-2). B) Fluorescence induction kinetics in relative units (r. u.) at low actinic light of dark-adapted cells followed by a saturating pulse after $3 \mathrm{~s}$ to determine $\mathrm{F}_{\mathrm{m}}$. Strains as in Fig. 2 from tetratype tetrad 1 grown on TAP plates at $6 \mu \mathrm{mol} \mathrm{m} \mathrm{m}^{-2}$. C) Fluorescence induction kinetics at low actinic light of dark-adapted cells in the presence (red) or absence (black) of the PSII-specific inhibitor DCMU. 2pac and 2pac ftshl-1 strains were grown in strongly aerated TAP liquid culture at 6 $\mu \mathrm{mol} \mathrm{m} \mathrm{s}^{-1}$.

Figure 5: Dark-grown 2pac ftsh1-1 displays variable fluorescence and accumulates a 23-kD fragment of the D1 protein. A) Fluorescence induction curves of dark-grown liquid cultures of 2pac (upper panel) and 2pac ftsh1-1 (lower panel) in the presence (red) or absence (black) of the PSII-specific inhibitor DCMU. An absence of DCMU-altered kinetics in 2pac indicates an absence of variable fluorescence and PSII activity $\left(\mathrm{F}_{\mathrm{v}} / \mathrm{F}_{\mathrm{m}}\right)$, whereas DCMU treatment reveals measurable $\mathrm{F}_{\mathrm{v}} / \mathrm{F}_{\mathrm{m}}$ in 2pac ftsh1-1. B) Immunoblot analysis of PSII subunit levels from darkgrown WT (4A+), 2pac, and 2pac ftsh 1-1. An antibody raised against a peptide from the stromal loop connecting helices D and E of the D1 protein ( $\alpha$-DE loop) recognizes both full-length D1 and a $23-\mathrm{kD}$ N-terminal fragment, both of which accumulate in dark-grown 2pac ftsh1-1.

Figure 6: BN-PAGE, immunoblot analysis, and absorption spectroscopy of PSII purified from wild-type and 2pac ftsh1-1 backgrounds. A) BN-PAGE analysis of Ni-affinity-purified PSII from H-HIS (strain bearing a His-tagged PsbH subunit of PSII) and 2pac ftsh 1-1 H-HIS (HHIS strain with 2pac and ftsh $1-1$ mutations introduced via crossing) showing the accumulation of PSII supercomplexes (SC), dimers (D), monomers (M), and RC47 subcomplexes (RC47). B) Immunoblot analysis of excised bands corresponding to PSII monomers from both strains, showing presence of PSII subunits. C) Reduced minus oxidized absorption spectra of isolated PSIIs from both strains showing peaks at $559 \mathrm{~nm}$, indicating the presence of the $b$-heme coordinated by cytochrome $b_{559}$.

Figure 7: Model showing the effect of RBD1 mutation on the folding/maturation of D1. WT D1 (left side) provides four ligands that directly or indirectly (via bicarbonate, green) coordinate the non-heme iron of PSII (red sphere). These direct ligands are located in helix D (H215), helix E (H272), and in the DE-loop (E244 and Y246) close to the DE loop peptide (residues 234-242: NEGYRFGQE). A conformational change of the DE-loop of D1 may occur in the 2pac mutant that lacks RBD1 (right side), resulting in proteolytic cleavage, possibly mediated by a Deg protease, followed by FtsH-mediated degradation. This conformational change may be due to the 
530 absence of the non-heme iron, which we propose may be delivered by RBD1 to D1 during the 531 assembly of PSII (model adapted from (Hippler et al., 1998; Kapri-Pardes et al., 2007; Malnoë et 532 al., 2014).

533

Table 1: PSII proteins identified via LC-MS/MS analysis of isolated PSII dimers from HHIS and H-HIS 2pac ftsh1-1 (T7A)

\begin{tabular}{|c|c|c|c|c|c|c|c|c|c|}
\hline $\begin{array}{c}\text { Protein } \\
\text { name }\end{array}$ & $\begin{array}{c}\text { Uniprot } \\
\text { No. }\end{array}$ & Gene & $\begin{array}{c}\text { Protein } \\
\text { MW } \\
(\mathbf{k D}) \\
\end{array}$ & $\begin{array}{c}\text { Peptide } \\
\text { MH+ } \\
\text { (D) } \\
\end{array}$ & Peptide Sequence & & $\begin{array}{c}\text { H-HIS } \\
\text { spectral } \\
\text { counts } \\
\end{array}$ & $\begin{array}{c}\text { T7A } \\
\text { spectral } \\
\text { counts } \\
\end{array}$ & \\
\hline \multirow[t]{13}{*}{ D1 } & P07753 & $\mathrm{psbA}$ & 39 & 1119.2 & R.RENSSLWAR.F & & 59 & 13 & \\
\hline & & & & 962.5 & R.ENSSLWAR.F & & 8 & 21 & \\
\hline & & & & 1444.2 & R.FCEWITSTENR.L & & 6 & 23 & \\
\hline & & & & 966.5 & R.EWELSFR.L & & 2 & 13 & \\
\hline & & & & 1500.3 & R.ETTENESANEGYR.F & & 6 & 6 & \\
\hline & & & & 2189.4 & R.FGQEEETYNIVAAHGYFGR.L & & 2 & 10 & \\
\hline & & & & 1459.9 & R.LIFQYASFNNSR.S & & 14 & 15 & \\
\hline & & & & 1314.7 & R.VLNTWADIINR.A & & 94 & 229 & \\
\hline & & & & 1288.3 & R.ANLGMEVMHER.N & & 10 & 33 & \\
\hline & & & & 1303.2 & R.ANLGMoxEVMHER.N & & 2 & 9 & $\#$ \\
\hline & & & & 1303.2 & R.ANLGMEVMoxHER.N & & 13 & 17 & $\#$ \\
\hline & & & & 1319.2 & R.ANLGMoxEVMoxHER.N & & 4 & 9 & $\#$ \\
\hline & & & & & & TOTAL & 220 & 398 & \\
\hline \multirow[t]{10}{*}{ D2 } & P06007 & $\mathrm{psbD}$ & 39 & 1441.2 & R.TWFDDADDWLR.Q & & 7 & 41 & \\
\hline & & & & 2031.3 & R.AFNPTQAEETYSMVTANR.F & & 11 & 22 & \\
\hline & & & & 2046.6 & R.AFNPTQAEETYSMoxVTANR.F & & 16 & 13 & \# \\
\hline & & & & 1227.8 & R.AYDFVSQEIR.A & & 48 & 19 & \\
\hline & & & & 1547.8 & R.AAEDPEFETFYTK.N & & 5 & 31 & \\
\hline & & & & 1041.7 & K.NILLNEGIR.A & & 71 & 67 & \\
\hline & & & & 1440.5 & R.AWMAAQDQPHER.L & & 13 & 29 & \\
\hline & & & & 1455.7 & R.AWMoxAAQDQPHER.L & & 20 & 23 & \# \\
\hline & & & & 1198.8 & R.LVFPEEVLPR.G & & 85 & 181 & \\
\hline & & & & & & TOTAL & 276 & 426 & \\
\hline \multirow[t]{7}{*}{$\begin{array}{l}\text { cytochrome } \\
b_{559} \text { alpha }\end{array}$} & P48268 & $\mathrm{psbE}$ & 9 & 1149.8 & R.PFSDILTSIR.Y & & 18 & 16 & \\
\hline & & & & 1170.6 & R.PNEYFTEDR.Q & & 7 & 6 & \\
\hline & & & & 1042.6 & R.QEAPLITDR.F & & 2 & 5 & \\
\hline & & & & 1973.1 & R.QEAPLITDRFNALEQVK.K & & 0 & 1 & \\
\hline & & & & 949.6 & R.FNALEQVK.K & & 37 & 29 & \\
\hline & & & & 1077.4 & R.FNALEQVKK.L & & 27 & 13 & \\
\hline & & & & & & TOTAL & 91 & 70 & \\
\hline
\end{tabular}




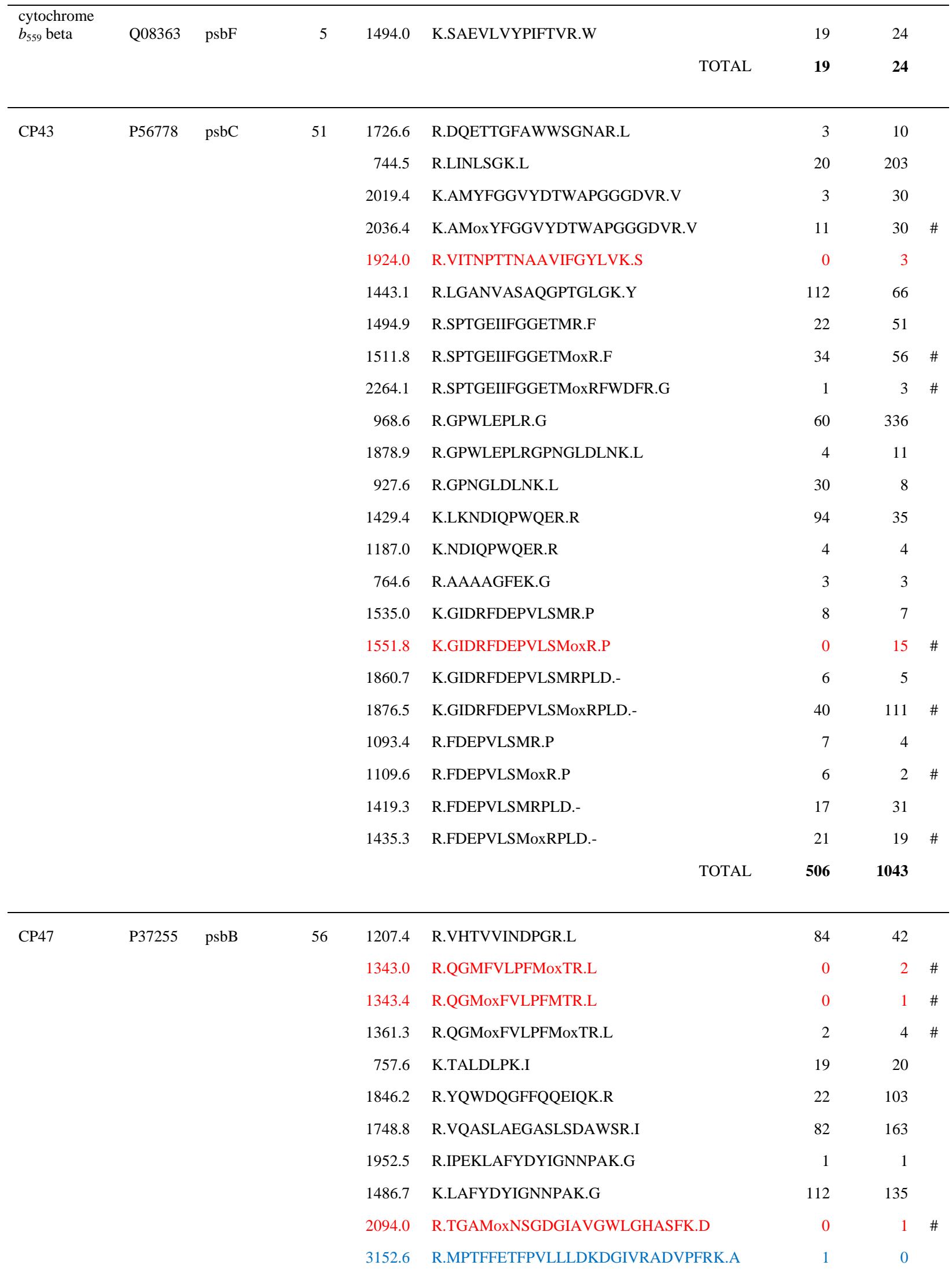




\begin{tabular}{|c|c|c|c|c|c|c|c|c|}
\hline & & & & 704.7 & R.ADVPFR.K & 3 & 2 & \\
\hline & & & & 833.3 & R.ADVPFRK.A & 0 & 16 & \\
\hline & & & & 1452.7 & R.KAQLGEIFEFDR.S & 0 & 1 & \\
\hline & & & & 1324.9 & K.AQLGEIFEFDR.S & 18 & 49 & \\
\hline & & & & 1109.5 & R.STLQSDGVFR.S & 28 & 26 & \\
\hline & & & & 1998.5 & R.DVFAGIDDDINDQVEFGK.Y & 18 & 30 & \\
\hline & & & & 976.9 & K.KLGDTSSLR.E & 29 & 43 & \\
\hline & & & & 848.6 & K.LGDTSSLR.E & 8 & 20 & \\
\hline & & & & & TOTAL & 427 & 659 & \\
\hline $\begin{array}{l}\text { PSII H } \\
\text { subunit }\end{array}$ & P22666 & $\mathrm{psbH}$ & 9 & 692.9 & -.MATGTSK.A & 1 & 0 & \\
\hline & & & & 2058.0 & K.VNSDFQEPGLVTPLGTLLR.P & 26 & 49 & \\
\hline & & & & 2855.1 & K.VNSDFQEPGLVTPLGTLLRPLNSEAGK.V & 0 & 2 & \\
\hline & & & & 815.7 & R.PLNSEAGK.V & 4 & 2 & \\
\hline & & & & & TOTAL & 31 & 53 & \\
\hline PSII OEE1 & P12853 & psbO & 31 & 1450.2 & R.LTYTLDAMoxSGSFK.V & 1 & 1 & $\#$ \\
\hline & & & & 1450.2 & R.GGSTGYDNAVALPAR.A & 2 & 2 & \\
\hline & & & & 1919.3 & K.GSGIANTCPVLESGTTNLK.E & 0 & 2 & \\
\hline & & & & & TOTAL & 3 & 5 & \\
\hline$\#=$ oxidized & thionine & & & & & & & \\
\hline Peptide dete & $\mathrm{d}$ only in $\mathrm{H}$ & HIS & & & & & & \\
\hline Peptide det & only in 7 & & & & & & & \\
\hline
\end{tabular}

\section{References}

Beale SI (2009) Chapter 20 - Biosynthesis of Chlorophylls and Hemes. In EH Harris, DB Stern, GB Witman, eds, The Chlamydomonas Sourcebook (Second Edition). Academic Press, London, pp 731-798 JD (1986) Characterization of photosystem II mutants of Chlamydomonas reinhardii lacking the psbA gene. Plant Mol Biol 6: 151-160 Vitry C, Niyogi KK (2013) A conserved rubredoxin is necessary for photosystem II accumulation in diverse oxygenic photoautotrophs. J Biol Chem 288: 26688-26696

Cullen M, Ray N, Husain S, Nugent J, Nield J, Purton S (2007) A highly active histidinetagged Chlamydomonas reinhardtii Photosystem II preparation for structural and biophysical analysis. Photochem Photobiol Sci 6: 1177-1183

De Las Rivas J, Andersson B, Barber J (1992) 2 Sites of Primary Degradation of the D1Protein Induced by Acceptor or Donor Side Photoinhibition in Photosystem-Ii Core Complexes. FEBS Letters 301: 246-252 
De Las Rivas J, Shipton CA, Ponticos M, Barber J (1993) Acceptor side mechanism of photoinduced proteolysis of the D1 protein in photosystem II reaction centers.

Biochemistry 32: 6944-6950

de Vitry C, Olive J, Drapier D, Recouvreur M, Wollman FA (1989) Posttranslational events leading to the assembly of photosystem II protein complex: a study using photosynthesis mutants from Chlamydomonas reinhardtii. J Cell Biol 109: 991-1006

García-Cerdán JG, Furst AL, McDonald KL, Schünemann D, Francis MB, Niyogi KK (2019) A thylakoid membrane-bound and redox-active rubredoxin (RBD1) functions in de novo assembly and repair of photosystem II. Proc Natl Acad Sci U S A 116: 1663116640

Gorman DS, Levine RP (1965) Cytochrome $f$ and plastocyanin - their sequence in the photosynthetic electron transport chain of Chlamydomonas reinhardtii. Proc Natl Acad Sci U S A 54: 1665-1669

Greenberg BM, Gaba V, Mattoo AK, Edelman M (1987) Identification of a primary in vivo degradation product of the rapidly-turning-over $32 \mathrm{kd}$ protein of photosystem II. EMBO J 6: $2865-2869$

Haussühl K, Andersson B, Adamska I (2001) A chloroplast DegP2 protease performs the primary cleavage of the photodamaged D1 protein in plant photosystem II. EMBO J 20: 713-722

Hemme D, Veyel D, Mühlhaus T, Sommer F, Jüppner J, Unger AK, Sandmann M, Fehrle I, Schönfelder S, Steup M, Geimer S, Kopka J, Giavalisco P, Schroda M (2014) Systems-wide analysis of acclimation responses to long-term heat stress and recovery in the photosynthetic model organism Chlamydomonas reinhardtii. Plant Cell 26: 42704297

Hippler M, Redding K, Rochaix JD (1998) Chlamydomonas genetics, a tool for the study of bioenergetic pathways. Biochim Biophys Acta 1367: 1-62

Huesgen PF, Schuhmann H, Adamska I (2006) Photodamaged D1 protein is degraded in Arabidopsis mutants lacking the Deg2 protease. FEBS Lett 580: 6929-6932

Johnson X, Vandystadt G, Bujaldon S, Wollman FA, Dubois R, Roussel P, Alric J, Béal D (2009) A new setup for in vivo fluorescence imaging of photosynthetic activity. Photosynth Res 102: 85-93

Kapri-Pardes E, Naveh L, Adam Z (2007) The thylakoid lumen protease Deg1 is involved in the repair of photosystem II from photoinhibition in Arabidopsis. Plant Cell 19: 10391047

Kato Y, Sakamoto W (2018) FtsH Protease in the Thylakoid Membrane: Physiological Functions and the Regulation of Protease Activity. Front Plant Sci 9: 855

Kato Y, Sun X, Zhang L, Sakamoto W (2012) Cooperative D1 degradation in the photosystem II repair mediated by chloroplastic proteases in Arabidopsis. Plant Physiol 159: 14281439

Kato Y, Watanabe H, Noguchi T (2021) ATR-FTIR Spectroelectrochemical Study on the Mechanism of the $\mathrm{pH}$ Dependence of the Redox Potential of the Non-Heme Iron in Photosystem II. Biochemistry 60: 2170-2178

Keren N, Berg A, van Kan PJ, Levanon H, Ohad I (1997) Mechanism of photosystem II photoinactivation and D1 protein degradation at low light: the role of back electron flow. Proc Natl Acad Sci U S A 94: 1579-1584 
Kiss É, Knoppová J, Aznar GP, Pilný J, Yu J, Halada P, Nixon PJ, Sobotka R, Komenda J (2019) A Photosynthesis-Specific Rubredoxin-Like Protein Is Required for Efficient Association of the D1 and D2 Proteins during the Initial Steps of Photosystem II Assembly. Plant Cell 31: 2241-2258

Knoppová J, Sobotka R, Yu J, Bečková M, Pilný J, Trinugroho JP, Csefalvay L, Bína D, Nixon PJ, Komenda J (2022) Assembly of D1/D2 complexes of photosystem II: binding of pigments and a network of auxiliary proteins. Plant Physiol

Komenda J, Reisinger V, Müller BC, Dobáková M, Granvogl B, Eichacker LA (2004) Accumulation of the D2 protein is a key regulatory step for assembly of the photosystem II reaction center complex in Synechocystis PCC 6803. J Biol Chem 279: 48620-48629

Komenda J, Sobotka R, Nixon PJ (2012) Assembling and maintaining the Photosystem II complex in chloroplasts and cyanobacteria. Curr Opin Plant Biol 15: 245-251

Kumar A, Prasad A, Sedlářová M, Kale R, Frankel LK, Sallans L, Bricker TM, Pospíšil P (2021) Tocopherol controls D1 amino acid oxidation by oxygen radicals in Photosystem II. Proc Natl Acad Sci U S A 118

Kuras R, Wollman FA (1994) The assembly of cytochrome b6/f complexes: an approach using genetic transformation of the green alga Chlamydomonas reinhardtii. EMBO J 13: 10191027

Laemmli UK (1970) Cleavage of structural proteins during the assembly of the head of bacteriophage T4. Nature 227: 680-685

Lindahl M, Spetea C, Hundal T, Oppenheim AB, Adam Z, Andersson B (2000) The thylakoid FtsH protease plays a role in the light-induced turnover of the photosystem II D1 protein. Plant Cell 12: 419-431

Lindahl M, Tabak S, Cseke L, Pichersky E, Andersson B, Adam Z (1996) Identification, characterization, and molecular cloning of a homologue of the bacterial FtsH protease in chloroplasts of higher plants. J Biol Chem 271: 29329-29334

Liu F, Geng J, Gumpper RH, Barman A, Davis I, Ozarowski A, Hamelberg D, Liu A (2015) An Iron Reservoir to the Catalytic Metal: THE RUBREDOXIN IRON IN AN EXTRADIOL DIOXYGENASE. J Biol Chem 290: 15621-15634

Lovenberg W, Sobel BE (1965) Rubredoxin: a new electron transfer protein from Clostridium pasteurianum. Proc Natl Acad Sci U S A 54: 193-199

Malnoë A, Wang F, Girard-Bascou J, Wollman FA, de Vitry C (2014) Thylakoid FtsH protease contributes to photosystem II and cytochrome b6f remodeling in Chlamydomonas reinhardtii under stress conditions. Plant Cell 26: 373-390

Malnoë A, Wollman FA, de Vitry C, Rappaport F (2011) Photosynthetic growth despite a broken Q-cycle. Nat Commun 2: 301

Miyao M, Ikeuchi M, Yamamoto N, Ono T (1995) Specific degradation of the D1 protein of photosystem II by treatment with hydrogen peroxide in darkness: implications for the mechanism of degradation of the D1 protein under illumination. Biochemistry 34: 1001910026

Mullet JE, Klein PG, Klein RR (1990) Chlorophyll regulates accumulation of the plastidencoded chlorophyll apoproteins CP43 and D1 by increasing apoprotein stability. Proc Natl Acad Sci U S A 87: 4038-4042

Nakajima Y, Yoshida S, Inoue Y, Ono T (1996) Occupation of the QB-binding pocket by a photosystem II inhibitor triggers dark cleavage of the D1 protein subjected to brief preillumination. J Biol Chem 271: 17383-17389 
Nickelsen J, Rengstl B (2013) Photosystem II assembly: from cyanobacteria to plants. Annu Rev Plant Biol 64: 609-635

Nixon PJ, Michoux F, Yu J, Boehm M, Komenda J (2010) Recent advances in understanding the assembly and repair of photosystem II. Ann Bot 106: 1-16

Ohad I, Kyle DJ, Arntzen CJ (1984) Membrane protein damage and repair: removal and replacement of inactivated 32-kilodalton polypeptides in chloroplast membranes. J Cell Biol 99: 481-485

Ramundo S, Casero D, Mühlhaus T, Hemme D, Sommer F, Crèvecoeur M, Rahire M, Schroda M, Rusch J, Goodenough U, Pellegrini M, Perez-Perez ME, Crespo JL, Schaad O, Civic N, Rochaix JD (2014) Conditional Depletion of the Chlamydomonas Chloroplast ClpP Protease Activates Nuclear Genes Involved in Autophagy and Plastid Protein Quality Control. Plant Cell 26: 2201-2222

Rappaport F, Béal D, Joliot A, Joliot P (2007) On the advantages of using green light to study fluorescence yield changes in leaves. Biochim Biophys Acta 1767: 56-65

Schottkowski M, Peters M, Zhan Y, Rifai O, Zhang Y, Zerges W (2012) Biogenic membranes of the chloroplast in Chlamydomonas reinhardtii. Proc Natl Acad Sci U S A 109: 19286-19291

Schroda M, de Vitry C (2022) Chaperones and Proteases. In U Goodenough, AR Grossman, FA Wollman, SK Dutcher, eds, The Chlamydomonas Sourcebook (Third Edition). Academic Press, London

Schroda M, Vallon O (2009) Chaperones and Proteases. In EH Harris, DB Stern, GB Witman, eds, The Chlamydomonas Sourcebook (Second Edition). Academic Press, London, pp 671-729

Schuhmann H, Huesgen PF, Adamska I (2012) The family of Deg/HtrA proteases in plants. BMC Plant Biol 12: 52

Shen G, Zhao J, Reimer SK, Antonkine ML, Cai Q, Weiland SM, Golbeck JH, Bryant DA (2002) Assembly of photosystem I. I. Inactivation of the rubA gene encoding a membrane-associated rubredoxin in the cyanobacterium Synechococcus sp. PCC 7002 causes a loss of photosystem I activity. J Biol Chem 277: 20343-20354

Spaniol B, Lang J, Venn B, Schake L, Sommer F, Mustas M, Geimer S, Wollman FA, Choquet Y, Mühlhaus T, Schroda M (2022) Complexome profiling on the Chlamydomonas lpa2 mutant reveals insights into PSII biogenesis and new PSII associated proteins. J Exp Bot 73: 245-262

Spetea C, Hundal T, Lohmann F, Andersson B (1999) GTP bound to chloroplast thylakoid membranes is required for light-induced, multienzyme degradation of the photosystem II D1 protein. Proc Natl Acad Sci U S A 96: 6547-6552

Sueoka N (1960) Mitotic replication of deoxyribonucleic acid in Chlamydomonas reinhardi. Proc Natl Acad Sci U S A 46: 83-91

Sun X, Fu T, Chen N, Guo J, Ma J, Zou M, Lu C, Zhang L (2010) The stromal chloroplast Deg7 protease participates in the repair of photosystem II after photoinhibition in Arabidopsis. Plant Physiol 152: 1263-1273

Theis J, Lang J, Spaniol B, Ferté S, Niemeyer J, Sommer F, Zimmer D, Venn B, Mehr SF, Mühlhaus T, Wollman FA, Schroda M (2019) The Chlamydomonas deglc mutant accumulates proteins involved in high light acclimation. Plant Physiol 181: 1480-1497

Umena Y, Kawakami K, Shen JR, Kamiya N (2011) Crystal structure of oxygen-evolving photosystem II at a resolution of $1.9 \AA$. Nature 473: 55-60 
bioRxiv preprint doi: https://doi.org/10.1101/2022.02.24.481860; this version posted February 26, 2022. The copyright holder for this preprint (which was not certified by peer review) is the author/funder, who has granted bioRxiv a license to display the preprint in perpetuity. It is made available under aCC-BY 4.0 International license.

691 Wastl J, Duin EC, Iuzzolino L, Dörner W, Link T, Hoffmann S, Sticht H, Dau H,

692 Lingelbach K, Maier UG (2000) Eukaryotically encoded and chloroplast-located

693 rubredoxin is associated with photosystem II. J Biol Chem 275: 30058-30063 


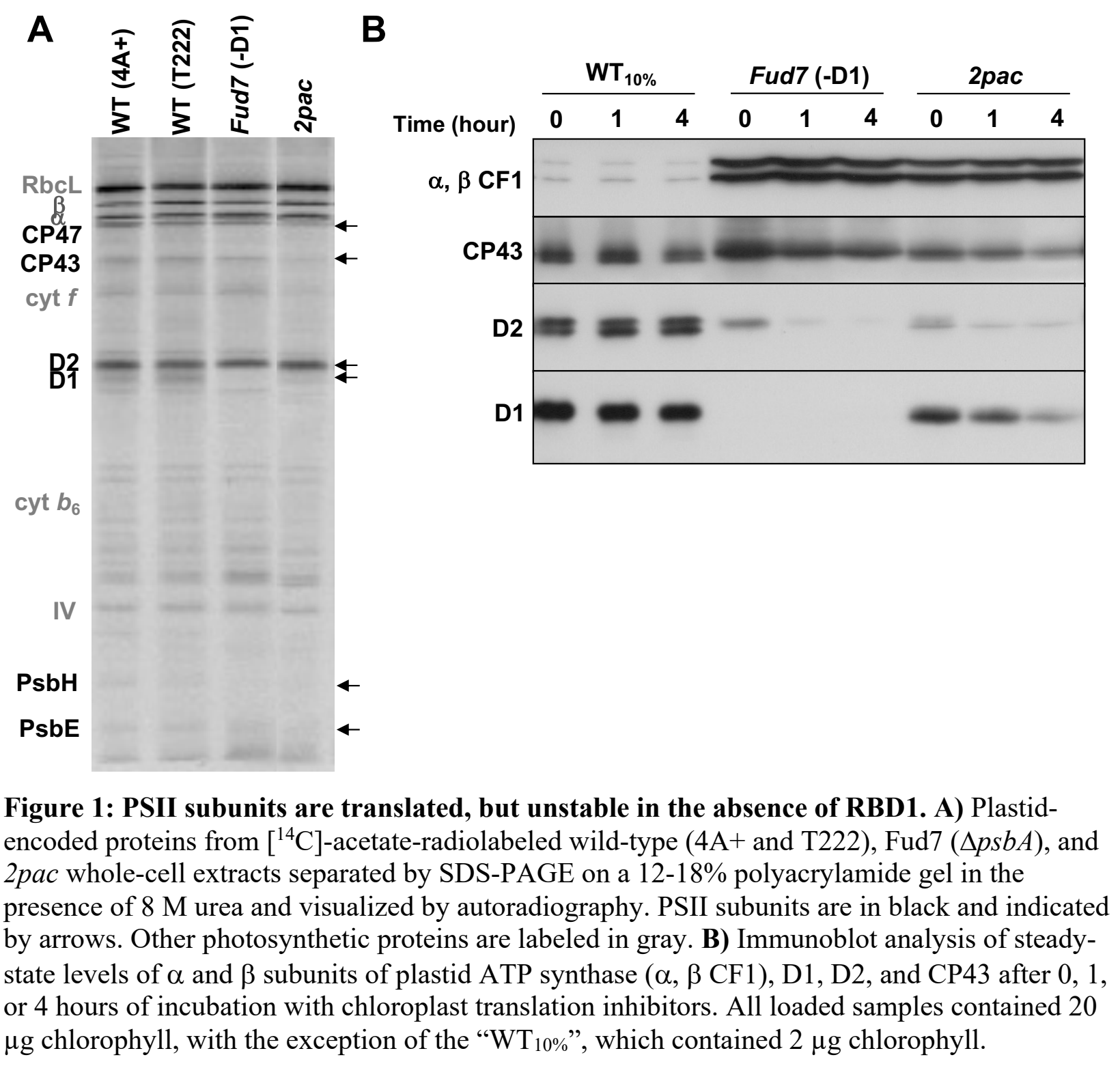




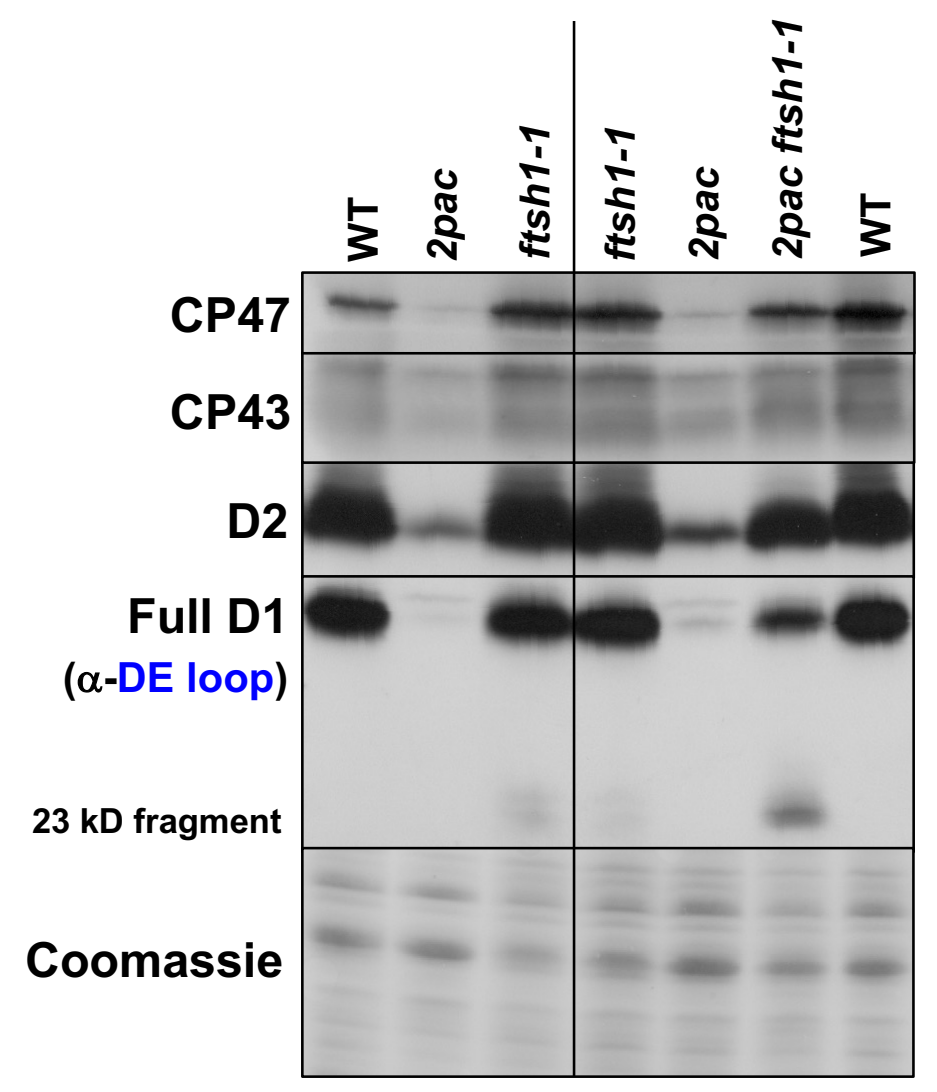

Figure 2: Inactivation of FtsH increases accumulation of PSII subunits in 2pac. Immunoblot analysis of PSII subunit levels from a representative tetrad (tetratype tetrad 1, right side) obtained by crossing $2 p a c$ and ftsh 1-1, with parental strains and wild-type as controls (left side). Whole-cell protein extracts from the strains grown in acetate-containing TAP medium at $6 \mu \mathrm{mol}$ photons $\mathrm{m}^{-2} \mathrm{~s}^{-1}$ were separated by SDS-PAGE on a 12-18\% polyacrylamide gel in the presence of $8 \mathrm{M}$ urea and immunodetected with antibodies against PSII subunits (CP47, CP43 and D2) and a peptide of the loop between the transmembrane helices D and E of D1 (D1-DE loop). Coomassie protein staining is provided as loading control. 

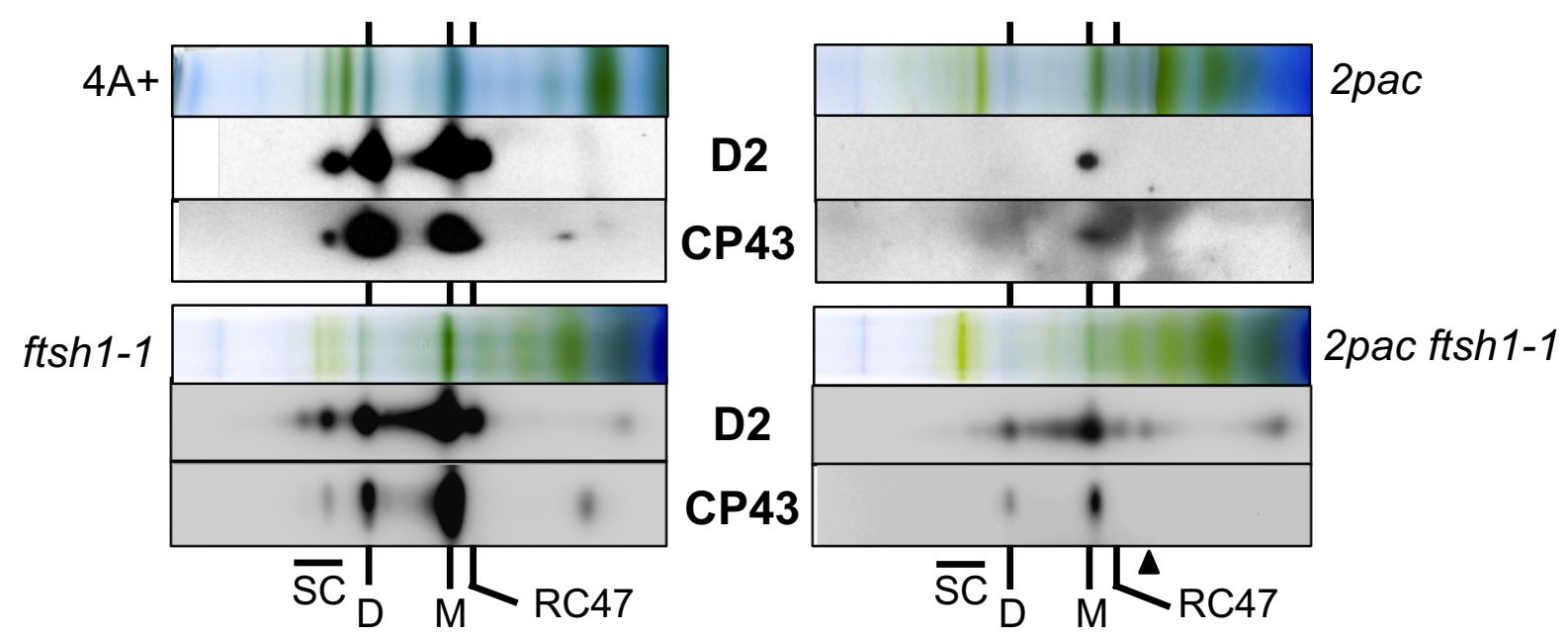

Figure 3: Two-dimensional blue native (BN)/SDS-PAGE analysis of PSII in 2pac ftsh1-1 relative to parental strains. Thylakoid membrane complexes from WT (4A+), ftsh 1-1, 2pac and 2 pac ftsh $1-1$ were solubilized with $1 \% \beta$-DM and separated by BN-PAGE (top panels), followed by SDS-PAGE in the second dimension and immunoblot analysis to detect D2 and CP43 (lower panels). SC, PSII super complex; D, PSII dimer; M, PSII monomer; RC47, CP43less PSII assembly intermediate (Komenda et al., 2004). Smaller complexes specifically detected in 2pac ftsh1-1 with antibodies against D2 are indicated by an arrow. 
A

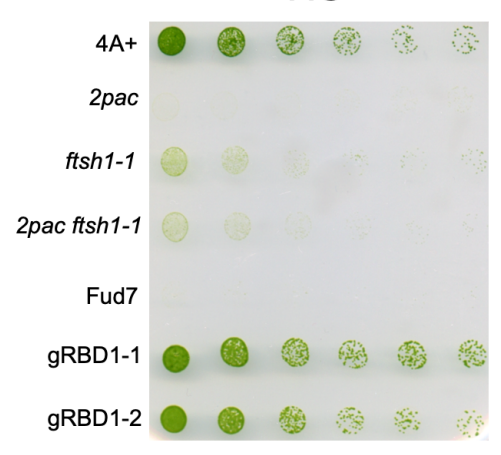

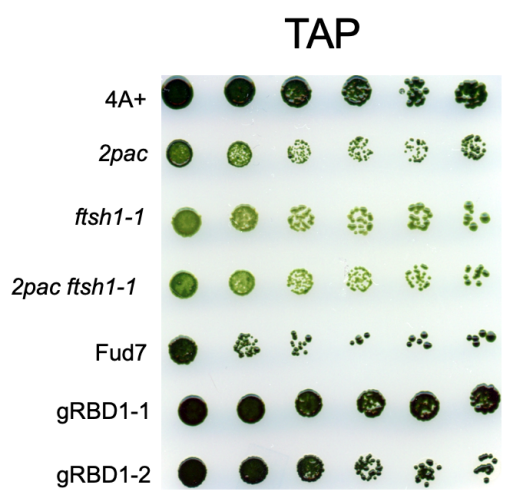

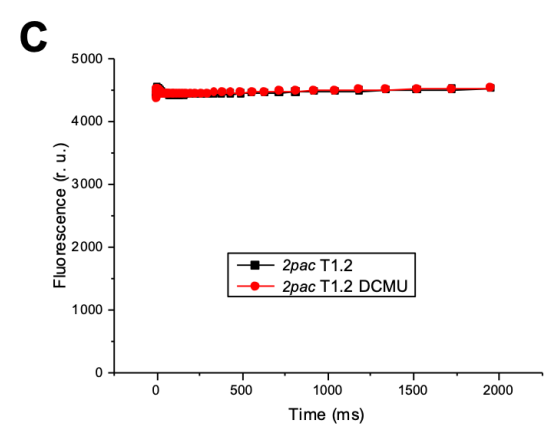

B

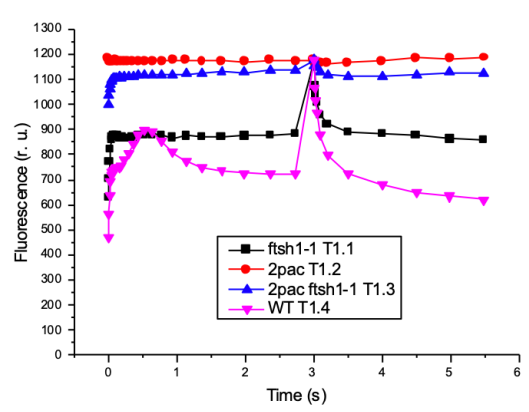

Figure 4: 2pac ftsh 1-1 grows photoautotrophically and displays low variable fluorescence. A) Growth on plates without (HS, left panel) and with (TAP, right panel) acetate at $30 \mu \mathrm{mol}$ photons $\mathrm{m}^{-2} \mathrm{~s}^{-1}$ of wild-type (4A+), 2pac, ftsh 1-1, 2pac ftsh 1-1, a strain lacking the $p s b A$ gene encoding the D1 protein (Fud7), and two complemented lines (gRBD1-1 and gRBD1-2). B) Fluorescence induction kinetics in relative units (r. u.) at low actinic light of dark-adapted cells followed by a saturating pulse after $3 \mathrm{~s}$ to determine $\mathrm{F}_{\mathrm{m}}$. Strains as in Fig. 2 from tetratype tetrad 1 grown on TAP plates at $6 \mu \mathrm{mol} \mathrm{m} \mathrm{m}^{-2} \mathrm{~s}^{-1}$. C) Fluorescence induction kinetics at low actinic light of darkadapted cells in the presence (red) or absence (black) of the PSII-specific inhibitor DCMU. 2pac and 2 pac ftsh 1-1 strains were grown in strongly aerated TAP liquid culture at $6 \mu \mathrm{mol} \mathrm{m} \mathrm{m}^{-2} \mathrm{~s}^{-1}$. 
A
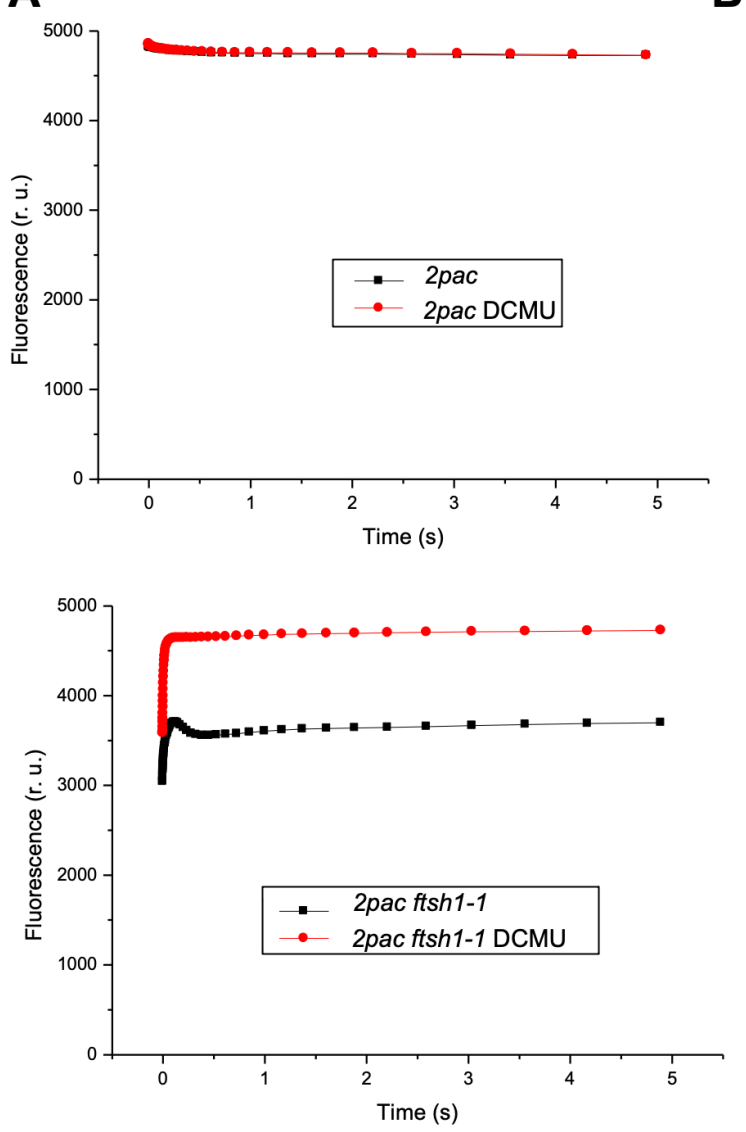

B

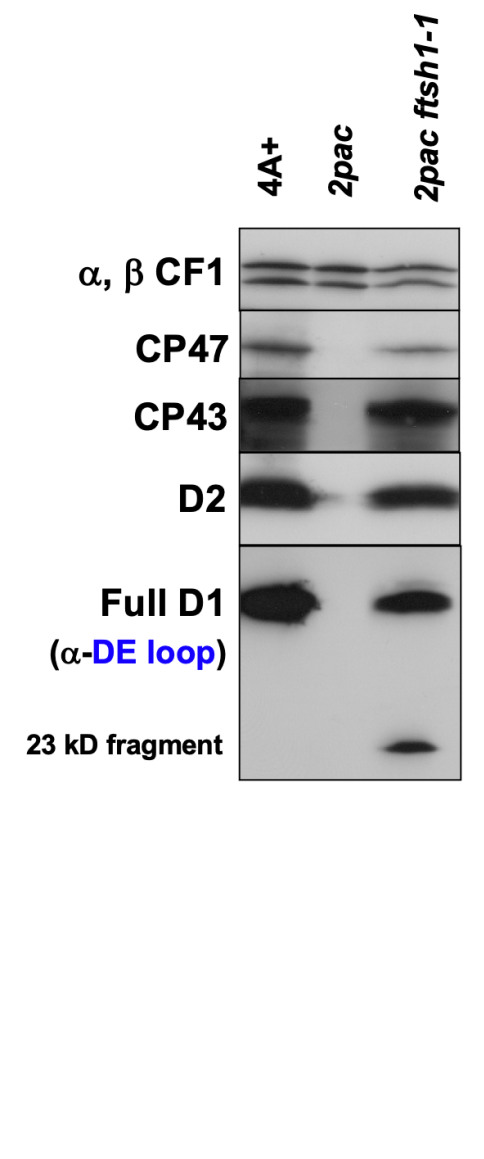

Figure 5: Dark-grown 2pac ftsh1-1 displays variable fluorescence and accumulates a 23-kD fragment of the D1 protein. A) Fluorescence induction curves of dark-grown liquid cultures of 2pac (upper panel) and 2pac ftsh1-1 (lower panel) in the presence (red) or absence (black) of the PSII-specific inhibitor DCMU. An absence of DCMU-altered kinetics in 2pac indicates an absence of variable fluorescence and PSII activity $\left(\mathrm{F}_{\mathrm{v}} / \mathrm{F}_{\mathrm{m}}\right)$, whereas DCMU treatment reveals measurable $\mathrm{F}_{\mathrm{v}} / \mathrm{F}_{\mathrm{m}}$ in $2 p a c$ ftsh 1-1. B) Immunoblot analysis of PSII subunit levels from dark-grown WT (4A+), 2pac, and 2pac ftsh 1-1. An antibody raised against a peptide from the stromal loop connecting helices D and E of the D1 protein ( $\alpha$-DE loop) recognizes both full-length D1 and a 23-kD Nterminal fragment, both of which accumulate in dark-grown 2pac ftsh 1-1. 
A

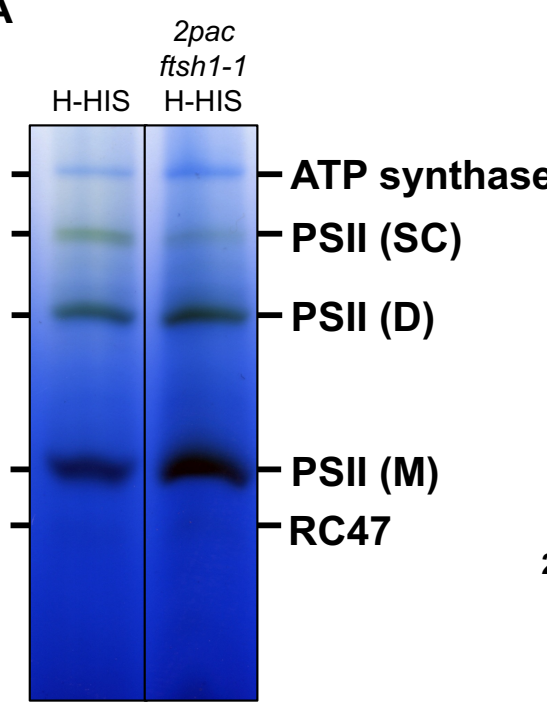

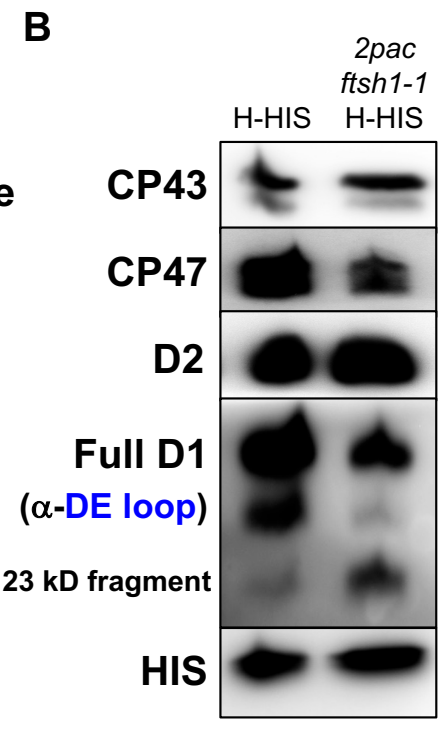

2 pac ftsh1-1

C

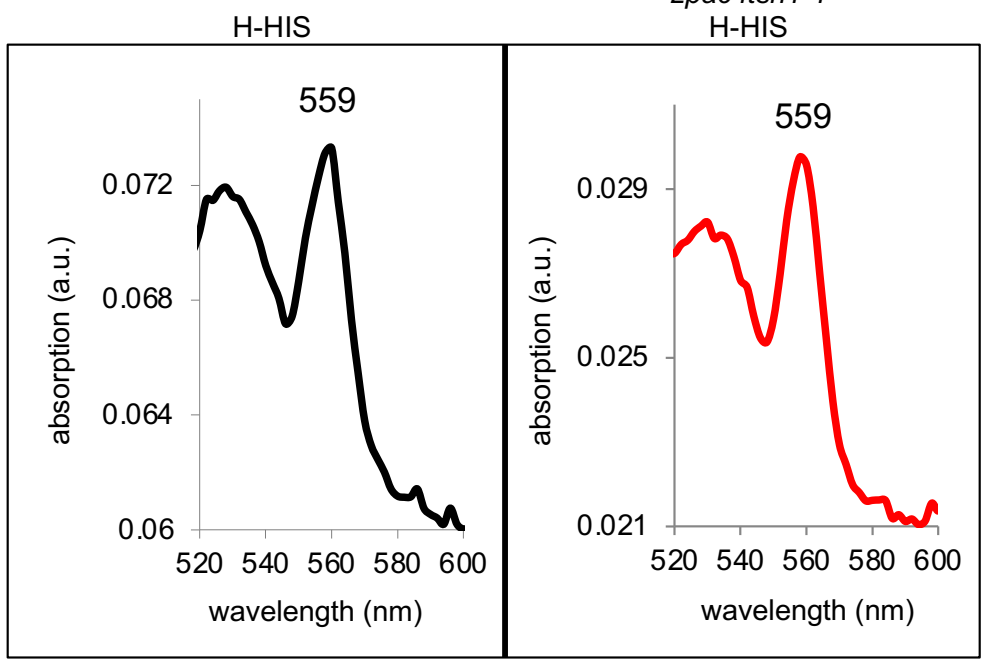

Figure 6: BN-PAGE, immunoblot analysis, and absorption spectroscopy of PSII purified from wild-type and 2pac ftsh1-1 backgrounds. A) BN-PAGE analysis of Ni-affinity-purified PSII from H-HIS (strain bearing a His-tagged PsbH subunit of PSII) and 2pac ftsh 1-1 H-HIS (HHIS strain with 2pac and ftsh $1-1$ mutations introduced via crossing) showing the accumulation of PSII supercomplexes (SC), dimers (D), monomers (M), and RC47 subcomplexes (RC47). B) Immunoblot analysis of excised bands corresponding to PSII monomers from both strains, showing presence of PSII subunits. C) Reduced minus oxidized absorption spectra of isolated PSIIs from both strains showing peaks at $559 \mathrm{~nm}$, indicating the presence of the $b$-heme coordinated by cytochrome $b_{559}$. 
WT D1

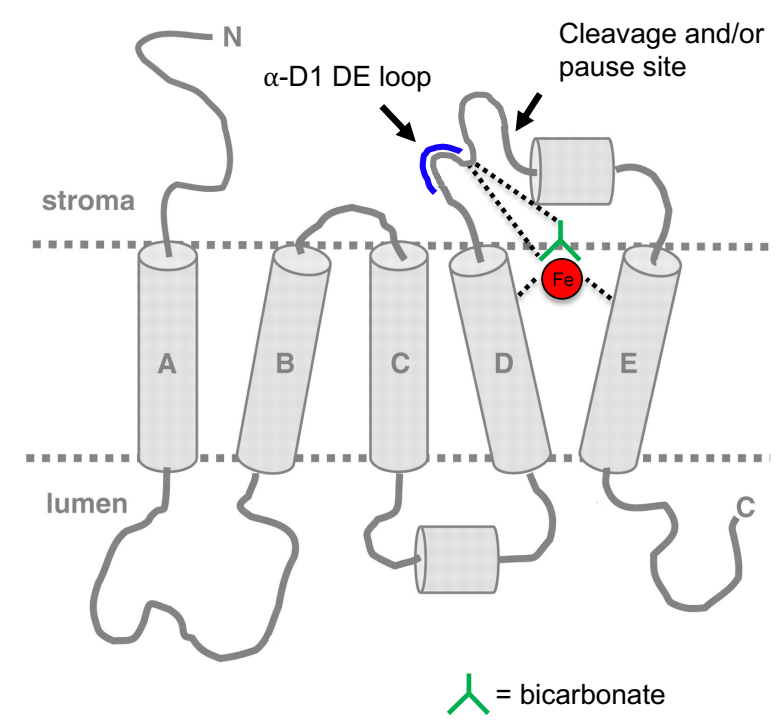

$2 p a c$ D1

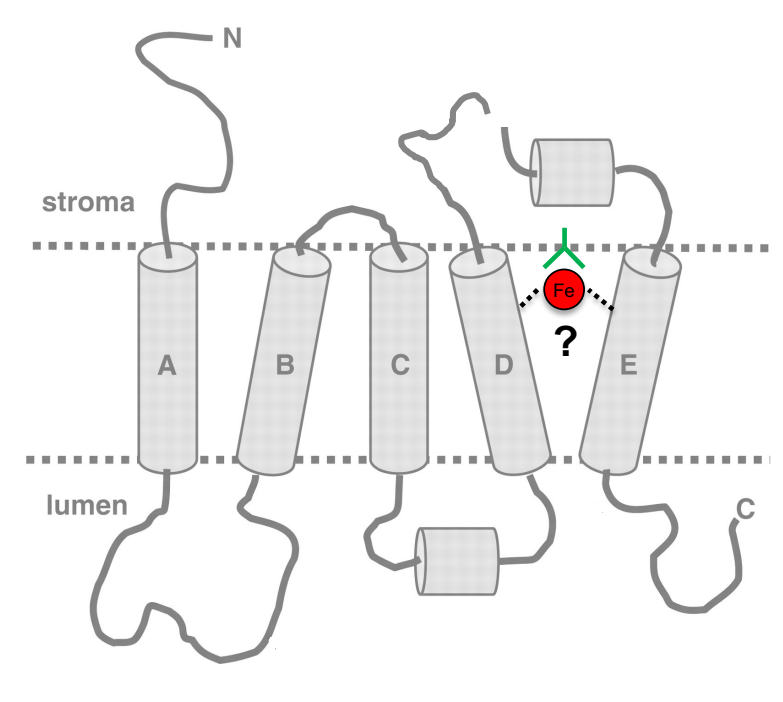

Figure 7: Model showing the effect of RBD1 mutation on the folding/maturation of D1. WT D1 (left side) provides four ligands that directly or indirectly (via bicarbonate, green) coordinate the non-heme iron of PSII (red sphere). These direct ligands are located in helix D (H215), helix E (H272), and in the DE-loop (E244 and Y246) close to the DE loop peptide (residues 234-242: NEGYRFGQE). A conformational change of the DE-loop of D1 may occur in the 2pac mutant that lacks RBD1 (right side), resulting in proteolytic cleavage, possibly mediated by a Deg protease, followed by FtsH-mediated degradation. This conformational change may be due to the absence of the non-heme iron, which we propose may be delivered by RBD1 to D1 during the assembly of PSII (model adapted from (Hippler et al., 1998; Kapri-Pardes et al., 2007; Malnoë et al., 2014). 


\section{Parsed Citations}

Beale SI (2009) Chapter 20 - Biosynthesis of Chlorophylls and Hemes. In EH Harris, DB Stern, GB Witman, eds, The Chlamydomonas Sourcebook (Second Edition). Academic Press, London, pp 731-798

Google Scholar: Author Only Title Only Author and Title

Bennoun P, Spierer-Herz M, Erickson J, Girard-Bascou J, Pierre Y, Delosme M, Rochaix JD (1986) Characterization of photosystem II mutants of Chlamydomonas reinhardii lacking the psbAgene. Plant Mol Biol 6: 151-160

Google Scholar: Author Only Title Only Author and Title

Calderon RH, Garcia-Cerdan JG, Malnoe A, Cook R, Russell JJ, Gaw C, Dent RM, de Vitry C, Niyogi KK (2013) Aconserved rubredoxin is necessary for photosystem II accumulation in diverse oxygenic photoautotrophs. J Biol Chem 288: 26688-26696

Google Scholar: Author Only Title Only Author and Title

Cullen M, Ray N, Husain S, Nugent J, Nield J, Purton S (2007) A highly active histidine-tagged Chlamydomonas reinhardtii

Photosystem II preparation for structural and biophysical analysis. Photochem Photobiol Sci 6: 1177-1183

Google Scholar: Author Only Title Only Author and Title

De Las Rivas J, Andersson B, Barber J (1992) 2 Sites of Primary Degradation of the D1-Protein Induced by Acceptor or Donor Side Photoinhibition in Photosystem-li Core Complexes. FEBS Letters 301: 246-252

Google Scholar: Author Only Title Only Author and Title

De Las Rivas J, Shipton CA, Ponticos M, Barber J (1993) Acceptor side mechanism of photoinduced proteolysis of the D1 protein in photosystem II reaction centers. Biochemistry 32: 6944-6950

Google Scholar: Author Only Title Only Author and Title

de Vitry C, Olive J, Drapier D, Recouvreur M, Wollman FA(1989) Posttranslational events leading to the assembly of photosystem II protein complex: a study using photosynthesis mutants from Chlamydomonas reinhardtii. J Cell Biol 109: 991-1006

Google Scholar: Author Only Title Only Author and Title

García-Cerdán JG, Furst AL, McDonald KL, Schünemann D, Francis MB, Niyogi KK (2019) Athylakoid membrane-bound and redox-active rubredoxin (RBD1) functions in de novo assembly and repair of photosystem II. Proc Natl Acad Sci U S A 116: 1663116640

Google Scholar: Author Only Title Only Author and Title

Gorman DS, Levine RP (1965) Cytochrome $f$ and plastocyanin - their sequence in the photosynthetic electron transport chain of Chlamydomonas reinhardtii. Proc Natl Acad Sci U S A 54: 1665-1669

Google Scholar: Author Only Title Only Author and Title

Greenberg BM, Gaba V, Mattoo AK, Edelman M (1987) Identification of a primary in vivo degradation product of the rapidlyturning-over $32 \mathrm{kd}$ protein of photosystem II. EMBO J 6: 2865-2869

Google Scholar: Author Only Title Only Author and Title

Haussühl K, Andersson B, Adamska I (2001) Achloroplast DegP2 protease performs the primary cleavage of the photodamaged D1 protein in plant photosystem II. EMBO J 20: 713-722

Google Scholar: Author Only Title Only Author and Title

Hemme D, Veyel D, Mühlhaus T, Sommer F, Jüppner J, Unger AK, Sandmann M, Fehrle I, Schönfelder S, Steup M, Geimer S, Kopka J, Giavalisco P, Schroda M (2014) Systems-wide analysis of acclimation responses to long-term heat stress and recovery in the photosynthetic model organism Chlamydomonas reinhardtii. Plant Cell 26: 4270-4297

Google Scholar: Author Only Title Only Author and Title

Hippler M, Redding K, Rochaix JD (1998) Chlamydomonas genetics, a tool for the study of bioenergetic pathways. Biochim Biophys Acta 1367: 1-62

Google Scholar: Author Only Title Only Author and Title

Huesgen PF, Schuhmann H, Adamska I (2006) Photodamaged D1 protein is degraded in Arabidopsis mutants lacking the Deg2 protease. FEBS Lett 580: 6929-6932

Google Scholar: Author Only Title Only Author and Title

Johnson X, Vandystadt G, Bujaldon S, Wollman FA, Dubois R, Roussel P, Aric J, Béal D (2009) Anew setup for in vivo fluorescence imaging of photosynthetic activity. Photosynth Res 102: 85-93

Google Scholar: Author Only Title Only Author and Title

Kapri-Pardes E, Naveh L, Adam Z (2007) The thylakoid lumen protease Deg1 is involved in the repair of photosystem Il from photoinhibition in Arabidopsis. Plant Cell 19: 1039-1047

Google Scholar: Author Only Title Only Author and Title

Kato Y, Sakamoto W(2018) FtsH Protease in the Thylakoid Membrane: Physiological Functions and the Regulation of Protease Activity. Front Plant Sci 9: 855 
Kato Y, Sun X, Zhang L, Sakamoto W(2012) Cooperative D1 degradation in the photosystem II repair mediated by chloroplastic proteases in Arabidopsis. Plant Physiol 159: 1428-1439

Google Scholar: Author Only Title Only Author and Title

Kato Y, Watanabe H, Noguchi T (2021) ATR-FTIR Spectroelectrochemical Study on the Mechanism of the pH Dependence of the

Redox Potential of the Non-Heme Iron in Photosystem II. Biochemistry 60: 2170-2178

Google Scholar: Author Only Title Only Author and Title

Keren N, Berg A, van Kan PJ, Levanon H, Ohad I (1997) Mechanism of photosystem Il photoinactivation and D1 protein degradation at low light: the role of back electron flow. Proc Natl Acad Sci U S A94: 1579-1584

Google Scholar: Author Only Title Only Author and Title

Kiss É, Knoppová J, Aznar GP, Pilný J, Yu J, Halada P, Nixon PJ, Sobotka R, Komenda J (2019) APhotosynthesis-Specific

Rubredoxin-Like Protein Is Required for Efficient Association of the D1 and D2 Proteins during the Initial Steps of Photosystem II

Assembly. Plant Cell 31: 2241-2258

Google Scholar: Author Only Title Only Author and Title

Knoppová J, Sobotka R, Yu J, Bečková M, Pilný J, Trinugroho JP, Csefalvay L, Bína D, Nixon PJ, Komenda J (2022) Assembly of D1/D2 complexes of photosystem II: binding of pigments and a network of auxiliary proteins. Plant Physiol

Google Scholar: Author Only Title Only Author and Title

Komenda J, Reisinger V, Müller BC, Dobáková M, Granvogl B, Eichacker LA(2004) Accumulation of the D2 protein is a key regulatory step for assembly of the photosystem II reaction center complex in Synechocystis PCC 6803. J Biol Chem 279: 4862048629

Google Scholar: Author Only Title Only Author and Title

Komenda J, Sobotka R, Nixon PJ (2012) Assembling and maintaining the Photosystem II complex in chloroplasts and cyanobacteria. Curr Opin Plant Biol 15: 245-251

Google Scholar: Author Only Title Only Author and Title

Kumar A, Prasad A, Sedlářová M, Kale R, Frankel LK, Sallans L, Bricker TM, Pospíšil P (2021) Tocopherol controls D1 amino acid oxidation by oxygen radicals in Photosystem II. Proc Natl Acad Sci U S A118

Google Scholar: Author Only Title Only Author and Title

Kuras R, Wollman FA(1994) The assembly of cytochrome b6/f complexes: an approach using genetic transformation of the green alga Chlamydomonas reinhardtii. EMBO J 13: 1019-1027

Google Scholar: Author Only Title Only Author and Title

Laemmli UK (1970) Cleavage of structural proteins during the assembly of the head of bacteriophage T4. Nature 227: 680-685

Google Scholar: Author Only Title Only Author and Title

Lindahl M, Spetea C, Hundal T, Oppenheim AB, Adam Z, Andersson B (2000) The thylakoid FtsH protease plays a role in the lightinduced turnover of the photosystem II D1 protein. Plant Cell 12: 419-431

Google Scholar: Author Only Title Only Author and Title

Lindahl M, Tabak S, Cseke L, Pichersky E, Andersson B, Adam Z (1996) Identification, characterization, and molecular cloning of a homologue of the bacterial FtsH protease in chloroplasts of higher plants. J Biol Chem 271: 29329-29334

Google Scholar: Author Only Title Only Author and Title

Liu F, Geng J, Gumpper RH, Barman A, Davis I, Ozarowski A, Hamelberg D, Liu A(2015) An Iron Reservoir to the Catalytic Metal:

THE RUBREDOXIN IRON IN AN EXTRADIOL DIOXYGENASE. J Biol Chem 290: 15621-15634

Google Scholar: Author Only Title Only Author and Title

Lovenberg W, Sobel BE (1965) Rubredoxin: a new electron transfer protein from Clostridium pasteurianum Proc Natl Acad Sci U S A54: 193-199

Google Scholar: Author Only Title Only Author and Title

Malnoë A, Wang F, Girard-Bascou J, Wollman FA, de Vitry C (2014) Thylakoid FtsH protease contributes to photosystem II and cytochrome b6f remodeling in Chlamydomonas reinhardtii under stress conditions. Plant Cell 26: 373-390

Google Scholar: Author Only Title Only Author and Title

Malnoë A, Wollman FA, de Vitry C, Rappaport F (2011) Photosynthetic growth despite a broken Q-cycle. Nat Commun 2: 301

Google Scholar: Author Only Title Only Author and Title

Miyao M, Ikeuchi M, Yamamoto N, Ono T (1995) Specific degradation of the D1 protein of photosystem II by treatment with hydrogen peroxide in darkness: implications for the mechanism of degradation of the D1 protein under illumination. Biochemistry 34: 10019-10026

Google Scholar: Author Only Title Only Author and Title 
Mullet JE, Klein PG, Klein RR (1990) Chlorophyll regulates accumulation of the plastid-encoded chlorophyll apoproteins CP43 and D1 by increasing apoprotein stability. Proc Natl Acad Sci U S A87: 4038-4042

Google Scholar: Author Only Title Only Author and Title

Nakajima Y, Yoshida S, Inoue Y, Ono T (1996) Occupation of the QB-binding pocket by a photosystem Il inhibitor triggers dark cleavage of the D1 protein subjected to brief preillumination. J Biol Chem 271: 17383-17389

Google Scholar: Author Only Title Only Author and Title

Nickelsen J, Rengstl B (2013) Photosystem II assembly: from cyanobacteria to plants. Annu Rev Plant Biol 64: 609-635

Google Scholar: Author Only Title Only Author and Title

Nixon PJ, Michoux F, Yu J, Boehm M, Komenda J (2010) Recent advances in understanding the assembly and repair of photosystem II. Ann Bot 106: 1-16

Google Scholar: Author Only Title Only Author and Title

Ohad I, Kyle DJ, Arntzen CJ (1984) Membrane protein damage and repair: removal and replacement of inactivated 32-kilodalton polypeptides in chloroplast membranes. J Cell Biol 99: 481-485

Google Scholar: Author Only Title Only Author and Title

Ramundo S, Casero D, Mühlhaus T, Hemme D, Sommer F, Crèvecoeur M, Rahire M, Schroda M, Rusch J, Goodenough U, Pellegrini M, Perez-Perez ME, Crespo JL, Schaad O, Civic N, Rochaix JD (2014) Conditional Depletion of the Chlamydomonas Chloroplast ClpP Protease Activates Nuclear Genes Involved in Autophagy and Plastid Protein Quality Control. Plant Cell 26: 2201-2222

Google Scholar: Author Only Title Only Author and Title

Rappaport F, Béal D, Joliot A, Joliot P (2007) On the advantages of using green light to study fluorescence yield changes in leaves. Biochim Biophys Acta 1767: 56-65

Google Scholar: Author Only Title Only Author and Title

Schottkowski M, Peters M, Zhan Y, Rifai O, Zhang Y, Zerges W (2012) Biogenic membranes of the chloroplast in Chlamydomonas reinhardtii. Proc Natl Acad Sci U S A 109: 19286-19291

Google Scholar: Author Only Title Only Author and Title

Schroda M, de Vitry C (2022) Chaperones and Proteases. In U Goodenough, AR Grossman, F-A Wollman, SK Dutcher, eds, The Chlamydomonas Sourcebook (Third Edition). Academic Press, London

Google Scholar: Author Only Title Only Author and Title

Schroda M, Vallon O (2009) Chaperones and Proteases. In EH Harris, DB Stern, GB Witman, eds, The Chlamydomonas

Sourcebook (Second Edition). Academic Press, London, pp 671-729

Google Scholar: Author Only Title Only Author and Title

Schuhmann H, Huesgen PF, Adamska I (2012) The family of Deg/HtrA proteases in plants. BMC Plant Biol 12: 52

Google Scholar: Author Only Title Only Author and Title

Shen G, Zhao J, Reimer SK, Antonkine ML, Cai Q, Weiland SM, Golbeck JH, Bryant DA (2002) Assembly of photosystem I. I. Inactivation of the rubAgene encoding a membrane-associated rubredoxin in the cyanobacterium Synechococcus sp. PCC 7002 causes a loss of photosystem I activity. J Biol Chem 277: 20343-20354

Google Scholar: Author Only Title Only Author and Title

Spaniol B, Lang J, Venn B, Schake L, Sommer F, Mustas M, Geimer S, Wollman FA, Choquet Y, Mühlhaus T, Schroda M (2022) Complexome profiling on the Chlamydomonas Ipa2 mutant reveals insights into PSII biogenesis and new PSIl associated proteins. J Exp Bot 73: 245-262

Google Scholar: Author Only Title Only Author and Title

Spetea C, Hundal T, Lohmann F, Andersson B (1999) GTP bound to chloroplast thylakoid membranes is required for lightinduced, multienzyme degradation of the photosystem II D1 protein. Proc Natl Acad Sci U S A96: 6547-6552

Google Scholar: Author Only Title Only Author and Title

Sueoka N (1960) Mitotic replication of deoxyribonucleic acid in Chlamydomonas reinhardi. Proc Natl Acad Sci U S A46: 83-91

Google Scholar: Author Only Title Only Author and Title

Sun X, Fu T, Chen N, Guo J, Ma J, Zou M, Lu C, Zhang L (2010) The stromal chloroplast Deg7 protease participates in the repair of photosystem II after photoinhibition in Arabidopsis. Plant Physiol 152: 1263-1273

Google Scholar: Author Only Title Only Author and Title

Theis J, Lang J, Spaniol B, Ferté S, Niemeyer J, Sommer F, Zmmer D, Venn B, Mehr SF, Mühlhaus T, Wollman FA, Schroda M (2019) The Chlamydomonas deg1c mutant accumulates proteins involved in high light acclimation. Plant Physiol 181: 1480-1497 Google Scholar: Author Only Title Only Author and Title

Umena Y, Kawakami K, Shen JR, Kamiya N (2011) Crystal structure of oxygen-evolving photosystem Il at a resolution of 1.9 A 
bioRxiv preprint doi: https://doi.org/10.1101/2022.02.24.481860; this version posted February 26, 2022. The copyright holder for this preprint (which was not certified by peer review) is the author/funder, who has granted bioRxiv a license to display the preprint in perpetuity. It is made Nature 473: 55-60 available under aCC-BY 4.0 International license.

Google Scholar: Author Only Title Only Author and Title

Wastl J, Duin EC, luzzolino L, Dörner W, Link T, Hoffmann S, Sticht H, Dau H, Lingelbach K, Maier UG (2000) Eukaryotically encoded and chloroplast-located rubredoxin is associated with photosystem II. J Biol Chem 275: 30058-30063

Google Scholar: Author Only Title Only Author and Title 